\title{
Article \\ Adsorption of Hexavalent Chromium and Divalent Lead Ions on the Nitrogen-Enriched Chitosan-Based Activated Carbon
}

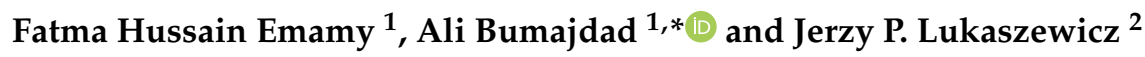 \\ 1 Chemistry Department, Faculty of Science, Kuwait University, P.O. Box 5969, Safat 13060, Kuwait; \\ fatemeh.emami@ku.edu.kw \\ 2 Centre for Modern Interdisciplinary Technologies, Nicolaus Copernicus University, Wilenska 4, \\ PL-87100 Torun, Poland; jerzy_lukaszewicz@o2.pl \\ * Correspondence: a.bumajdad@ku.edu.kw
}

check for updates

Citation: Emamy, F.H.; Bumajdad, A.; Lukaszewicz, J.P. Adsorption of Hexavalent Chromium and Divalent Lead Ions on the Nitrogen-Enriched Chitosan-Based Activated Carbon. Nanomaterials 2021, 11, 1907. https:// doi.org/10.3390/nano11081907

Academic Editor: George Z. Kyzas

Received: 14 June 2021

Accepted: 20 July 2021

Published: 24 July 2021

Publisher's Note: MDPI stays neutral with regard to jurisdictional claims in published maps and institutional affiliations.

Copyright: (c) 2021 by the authors. Licensee MDPI, Basel, Switzerland. This article is an open access article distributed under the terms and conditions of the Creative Commons Attribution (CC BY) license (https:// creativecommons.org/licenses/by/ $4.0 /)$.

\begin{abstract}
Optimizing the physicochemical properties of the chitosan-based activated carbon (ChACs) can greatly enhance its performance toward heavy metal removal from contaminated water. Herein, Ch was converted into a high surface area $\left(1556 \mathrm{~m}^{2} / \mathrm{g}\right)$ and porous $\left(0.69 \mathrm{~cm}^{3} / \mathrm{g}\right)$ ACs with large content of nitrogen $(\sim 16 \mathrm{wt} \%)$ using $\mathrm{K}_{2} \mathrm{CO}_{3}$ activator and urea as nitrogen-enrichment agents. The prepared $\mathrm{Ch}$-ACs were tested for the removal of $\mathrm{Cr}(\mathrm{VI})$ and $\mathrm{Pb}$ (II) at different $\mathrm{pH}$, initial metal ions concentration, time, activated carbon dosage, and temperature. For $\mathrm{Cr}(\mathrm{VI})$, the best removal was at $\mathrm{pH}=2$, while for $\mathrm{Pb}$ (II) the best $\mathrm{pH}$ for its removal was in the range of $4-6$. At $25{ }^{\circ} \mathrm{C}$, the Temkin model gives the best fit for the adsorption of $\mathrm{Cr}(\mathrm{VI})$, while the Langmuir model was found to be better for $\mathrm{Pb}(\mathrm{II})$ ions. The kinetics of adsorption of both heavy metal ions were found to be well-fitted by a pseudo-second-order model. The findings show that the efficiency and the green properties (availability, recyclability, and cost effectiveness) of the developed adsorbent made it a good candidate for wastewaters treatment. As preliminary work, the prepared sorbent was also tested regarding the removal of heavy metals and other contaminations from real wastewater and the obtained results were found to be promising.
\end{abstract}

Keywords: heavy metal ion removal; undersea biomass; green adsorbent; potassium carbonate; Langmuir; Freundlich; kinetic model; biowaste material; aqueous waste; adsorption efficiency

\section{Introduction}

Activated carbon (AC) is a universally used adsorbent for different applications, including industrial wastewater treatment. Such applications of AC are related to its high porosity (hence, large surface area) with a broad range of pore size, thermal stability, flexibility, presence of several functional group at its surface, and its uncomplicated way of operation toward toxic pollutants. The appearance of functional groups on the surface of the ACs depends on many factors, such as the AC-parent material, the conditions of the preparation method, the type of the activator, the employed activation method, and the used doping agent [1-6].

ACs can be produced from low-cost, abundant, and/or eco-friendly materials, such as sea food waste, wood, coal, agricultural and industrial wastes. In general, the two main steps in the preparation of AC are carbonization and activation. Another step which can help is $\mathrm{N}$ enrichment (also called $\mathrm{N}$-doping in the literature) to modify the surface composition of the AC. Using a different source of nitrogen for surface modification will provide the ACs with additional physiochemical properties, which is beneficial in many applications [7].

Chitosan (Ch) is a biopolymer produced by deacetylation of regularly available biopolymer, chitin. Ch is a well-known source of AC with many applications, such as control drug delivery [8,9], heavy metal removal from water [10,11], hydrogen storage [12], 
catalytic and electrochemical plating [13,14], deionization of low-salinity water [15], pharmaceuticals residue removal [16], cationic and anionic dye adsorption [17], removal of pesticides [4], supercapacitor [18], and environmental applications [9]. In addition to the hydroxyl groups $(-\mathrm{OH})$, Ch structure also contains amino groups $\left(-\mathrm{NH}_{2}\right)$ which is linked to a chain of six-member saccharide rings. Due to the presence of such group, chitosan-based activated carbons (Ch-ACs) are characterized by a high nitrogen $(\mathrm{N})$ content (usually in the range of $6-11 \mathrm{wt} \%[19,20])$. Carbonizing the $\mathrm{Ch}$ in the presence of alkali metal salts gives promising properties. These compounds are well-known as activating agents [20-22].

Heavy metal ions are generated, in large amounts, throughout the industrial activities which then contaminate the environment and the living organisms. Metal ions are non-biodegradable and may cause disorders in plants and animals [23-25]. No fewer than 20 metals are categorized as toxic and most of them are discharged into the environment in large amounts which causes risks to human health. Thus, removing them from aqueous solutions is both important and challenging. There are several methods of heavy metal ion removal from contaminated water but the best is adsorption using a suitable sorbent $[16,23,26]$. The presence of different functional groups in the AC structure, including those associated with oxygen such as carboxyl, lactone, phenol, carbonyl and quinones, pyrene, and ether, and those associated with nitrogen, such as pyrrole, pyridine, pyridone amine, amide, quaternary nitrogen, imine and nitro [27], might be beneficial for heavy metal ion removal using carbonaceous sorbents. This study targeted the removal of $\mathrm{Cr}(\mathrm{VI})$ and $\mathrm{Pb}(\mathrm{II})$ ions using $\mathrm{ACs}$ produced from the Ch biomass. $\mathrm{Cr}(\mathrm{VI})$ ions is known to be 100 times more toxic than $\mathrm{Cr}$ (III) and this is due to its high water solubility, easy penetrability through cell membrane, mobility, oxidation, and carcinogenic properties [23,28-30]. $\mathrm{Pb}$ (II) ions are present in many industrial processes [31] and are also very toxic and cause damage to human brain, liver, kidney, and reproductive system and can unfavorably affect brain functions. Moreover, it causes headaches, dizziness, muscle weakness, and irritability [32,33].

In the literature, Ch-based AC preparation was a target for many researchers. Kucinska et al. studied a way to convert $\mathrm{Ch}$ into a high surface area and porous ACs by impregnating $\mathrm{Na}_{2} \mathrm{CO}_{3}$ solution to $\mathrm{Ch}$ followed by heat treating the wet $\mathrm{Ch}$ paste (at $600{ }^{\circ} \mathrm{C}$ ) and $\mathrm{HCl}$ etching. The obtained sorbent was of moderately high surface area (above $400 \mathrm{~m}^{2} / \mathrm{g}$ ), microporous and nitrogen-rich [20]. Ilnicka et al. studied the effect of adding different volumes of $\mathrm{Na}_{2} \mathrm{CO}_{3}$ activator and the use of different carbonization temperatures on the development of $S_{\mathrm{BET}}$ and pore structure of the prepared ACs. The prepared ACs were found to exhibit reasonable porosity (total pore volumes, $V_{\text {tot }}=0.58 \mathrm{~cm}^{3} / \mathrm{g}$ ) with high $S_{\text {BET }}\left(1148 \mathrm{~m}^{2} / \mathrm{g}\right)$. After treating the materials with urea $(\mathrm{U})$, the amount of nitrogen $(\mathrm{N})$ increased from $2.4-6.5$ to $13 \mathrm{wt} \%$ but such content of $\mathrm{N}$ decreases to half its value by increasing the treatment temperature from 600 to $800{ }^{\circ} \mathrm{C}$ [22]. Fujiki et al. studied Ch-ACs using different alkali carbonates, such as $\mathrm{Na}_{2} \mathrm{CO}_{3}, \mathrm{~K}_{2} \mathrm{CO}_{3}, \mathrm{Rb}_{2} \mathrm{CO}_{3}$, and $\mathrm{Cs}_{2} \mathrm{CO}_{3}$ [21]. They found that, at the same activation temperatures and activator loadings, the obtained $S_{\mathrm{BET}}$, $V_{\text {tot }}$, and $d_{\mathrm{p}}$ of the products increased, according to the degree of reactivity of the carbonate salts, in the following order: AC-Na $<$ AC-K $<$ AC-Rb $<$ AC-Cs [21]. In another publication, porous carbon support was prepared from $\mathrm{Ch}$ and $\mathrm{K}_{2} \mathrm{CO}_{3}$ at different carbonization temperatures. At $600{ }^{\circ} \mathrm{C}$, the $S_{\mathrm{BET}}$ were found to be $1154 \mathrm{~m}^{2} / \mathrm{g}$ and the porosity was $V_{\text {tot }}=0.566 \mathrm{~cm}^{3} / \mathrm{g}$ and $V_{\text {micro }}=0.502 \mathrm{~cm}^{3} / \mathrm{g}$, and by increasing the temperature to $800{ }^{\circ} \mathrm{C}$, the $S_{\mathrm{BET}}$ reached $2908 \mathrm{~m}^{2} / \mathrm{g}$ with $V_{\text {tot }}=1.418 \mathrm{~cm}^{3} / \mathrm{g}$ and $V_{\text {micro }}=1.317 \mathrm{~cm}^{3} / \mathrm{g}$ [34]. Other researchers prepared $\mathrm{N}$-rich $\mathrm{AC}$ by using another biomass (lignin) as a source of $\mathrm{AC}$ with $\mathrm{K}_{2} \mathrm{CO}_{3}$ as activator and $\mathrm{U}$ as $\mathrm{N}$ source [35]. They found that, after $900{ }^{\circ} \mathrm{C}$ thermal treatment, the $S_{\mathrm{BET}}$ significantly increased from $540 \mathrm{~m}^{2} / \mathrm{g}$ (for $\mathrm{K}_{2} \mathrm{CO}_{3}$-activated lignin in the absence of $\mathrm{U}$ ) to $3400 \mathrm{~m}^{2} / \mathrm{g}$ when $\mathrm{AC}$ generated from $\mathrm{K}_{2} \mathrm{CO}_{3}$-activated lignin in the presence of $\mathrm{U}$. They also observed scientific evidence that the presence of $\mathrm{K}_{2} \mathrm{CO}_{3}$ greatly reduce the escape of nitrogen (as $\mathrm{N}$-containing gases) during the carbonization, which results in a high $\mathrm{N}$ content in the solid ACs [35]. In another study, porous nitrogen-containing activated carbons (N-ACs) were prepared by Wang et al. using $\mathrm{Ch}$ and $\mathrm{LiCl}-\mathrm{ZnCl}_{2}$ molten salt in 
one-step carbonization with $\mathrm{Ch}$ to a molten salt-mass ratio equal to $3: 1$. The obtained $S_{\text {BET }}$ was $2025 \mathrm{~m}^{2} / \mathrm{g}$ and the $\mathrm{N}$ content was around $5 \mathrm{wt} \%$ [36]. In this context, many other researchers used $\mathrm{KOH}$ as activator for preparing a Ch-AC [12-15,37,38]. For example, Wrobel-Iwaniec et al. activated $\mathrm{Ch}$ using $\mathrm{KOH}$ with different temperature $\left(700\right.$ and $\left.800{ }^{\circ} \mathrm{C}\right)$, and Ch-to-KOH ratios, and the resulting Ch-based ACs were of high $S_{\mathrm{BET}}\left(922-3066 \mathrm{~m}^{2} / \mathrm{g}\right)$ and high $V_{\text {tot }}\left(0.40-1.38 \mathrm{~cm}^{3} / \mathrm{g}\right)$ [12]. Olejniczak et al. studied the synthesis of nitrogencontaining mesoporous carbons using $\mathrm{Ch}$ and colloidal silica as template [19]. Liu et al. prepared Ch-modified N-doped porous carbon composite (Ch-NPC) using Ch as a source of $\mathrm{N}$ and phenolic resin as a source of carbon followed by carbonization using $\mathrm{ZnCl}_{2}$ as activator [39]. The produced AC possesses a high $S_{\text {BET }}\left(2190 \mathrm{~m}^{2} / \mathrm{g}\right)$ with reasonable micropores $\left(V_{\text {micro }}=0.494 \mathrm{~cm}^{3} / \mathrm{g}\right)$ and mesopores $\left(V_{\text {meso }}=0.629 \mathrm{~cm}^{3} / \mathrm{g}\right)$ volume. The amount of $\mathrm{N}$ content increased after adding $\mathrm{Ch}$ from 2.05 to $4.74 \mathrm{wt} \%$.

It is very clear from the literature survey that only few publications are concerned with converting $\mathrm{Ch}$ to $\mathrm{ACs}$ and none of them were tested for $\mathrm{Cr}(\mathrm{VI})$ and $\mathrm{Pb}(\mathrm{II})$ removal. Most of the focus was given to as-is $\mathrm{Ch}$ [40] or complex/composite formation between $\mathrm{Ch}$ and AC rather than carbonization of the $\mathrm{Ch}$ to produced $\mathrm{N}$-rich $\mathrm{AC}[20,41]$. The purpose of this work, however, is to purify water from two heavy metal ions (the hexavalent chromium, $\mathrm{Cr}(\mathrm{VI})$, and the divalent lead, $\mathrm{Pb}(\mathrm{II})$ ) using $\mathrm{AC}$ s prepared from the readily available $\mathrm{Ch}$ as a nitrogen-rich source of carbonaceous sorbent (Ch-ACs), $\mathrm{K}_{2} \mathrm{CO}_{3}$ as activator, and $\mathrm{U}$ as a prominent N-enrichment material. Our work shows that the prepared Ch-ACs is of high $S_{\mathrm{BET}}$ and high meso- and microporosity, but more importantly, it possesses the highest $\mathrm{N}$ content $(16 \mathrm{wt} \%)$ among those reported in the literature for such materials. To the best of our knowledge, this is the first study that uses $\mathrm{K}_{2} \mathrm{CO}_{3}$ as activator and $\mathrm{U}$ as $\mathrm{N}$-doping agent for the preparation of Ch-AC. Only two studies [21,34] used $\mathrm{K}_{2} \mathrm{CO}_{3}$ (but without U) which produces, at similar carbonaceous temperature, less $S_{\mathrm{BET}}$ and less N-content than that reported by this study. With regard to the $\mathrm{Cr}(\mathrm{VI})$ and $\mathrm{Pb}(\mathrm{II})$ removal using $\mathrm{Ch}-\mathrm{AC}$, to our knowledge, this work is also the first to be reported.

\section{Materials and Methods}

\subsection{Materials}

Chitosan (Ch) (degree of deacetylation: 75-85 \%, Mwt: 190,000-310,000), hexylamine (HA), purity 99\%, ethylamine (EA), 66.0-72.0\% in water, 1,2-diaminopropane (DAP), purity $99 \% \mathrm{~N}, \mathrm{~N}-$ dimethyldodecylamine (DDA), purity $97 \%$, potassium carbonate, $\mathrm{K}_{2} \mathrm{CO}_{3}$, purity over $99 \%$, sodium carbonate, $\mathrm{Na}_{2} \mathrm{CO}_{3}$, purity over $99.5 \%$, potassium hydroxide, $\mathrm{KOH}$, purity $>85 \%$, urea (U), purity over $99.5 \%$, aniline (A), purity over $99.5 \%$, chromium(VI) oxide, $\mathrm{CrO}_{3}$, purity $99.9 \%$, and lead(II) nitrate, $\mathrm{Pb}\left(\mathrm{NO}_{3}\right)_{2}$, purity more than $99.0 \%$ were all purchased from Sigma-Aldrich (Schnelldorf, Germany). Dimethyldidodicylammonium bromide, DDAB, was prepared in our laboratory as described [42]. $\mathrm{CaCO}_{3}$ nanoparticle (NPs) was purchased from Sky spring nanomaterials, (Houston, TX, USA) purity 99\% and $\mathrm{HCl}$ (36.5-36 vol \%) was purchased from J.T.Baker. All reagents and solvents were of analytical grade and were used without further purification. The $\mathrm{N}_{2}$ gas used was $99.999 \%$ pure (KOAC, Kuwait). All solutions were prepared with deionized water of a resistivity of $18.2 \mathrm{M} \Omega . \mathrm{cm}$.

\subsection{Synthesis of Chitosan-Based Activated Carbon}

Different weight of pure dry Ch (5 or $10 \mathrm{~g}$ ) were mixed with 3 or $6 \mathrm{~mL}$ of concentrated $\mathrm{HCl}$ and 5 or $10 \mathrm{~mL}$ of distilled water. After that, the activator was dissolved $\left(\mathrm{K}_{2} \mathrm{CO}_{3}\right.$, $\left.\mathrm{Na}_{2} \mathrm{CO}_{3}\right)$ or mixed $\left(\mathrm{CaCO}_{3} \mathrm{NPs}\right)$ in distilled water and then impregnated into the Ch paste in different volumes (20 or $60 \mathrm{~mL}$ ), at a fixed activator concentration equal to $1.93 \mathrm{M}$. Then, the $\mathrm{Ch}$ with activator was transferred into a quartz boat, kept inside a quartz tube of a Carbolite STF15/180 furnace (Keison Products, Chelmsford, UK) and heated up to $600{ }^{\circ} \mathrm{C}$ under $\mathrm{N}_{2}$ (flow rate $=38^{\circ} \mathrm{C} / \mathrm{min}$ ), and it was held for $1 \mathrm{~h}$ at that carbonization temperature. After carbonization, the ACs were cooled down in the furnace under $\mathrm{N}_{2}$ flow, then etched with concentrated $\mathrm{HCl}$ for $20 \mathrm{~min}$ to remove the cations $\left(\mathrm{Na}^{+}, \mathrm{K}^{+}\right.$and $/$or $\left.\mathrm{Ca}^{2+}\right)$ and washed 
with distilled water until almost neutral ( $\mathrm{pH}$ of solution reached 6-7). For activation with $\mathrm{KOH}$, dry carbonized $\mathrm{Ch}$ was sucked into saturated $\mathrm{KOH}$ solution in a Binder FD 115 oven (BINDER, Tuttlingen, Germany) at $120^{\circ} \mathrm{C}$ overnight and then cooled down and carbonized in the furnace at $600{ }^{\circ} \mathrm{C}$ for $1 \mathrm{~h}$ under flow of $\mathrm{N}_{2}$. The sample was then collected and washed with distilled water to remove residual alkalinity.

\subsection{N Enrichment of Chitosan-Based Activated Carbon}

The used $\mathrm{N}$ doping reagents were HA, EA, DAP, DDA, U, A, or DDAB. After the activation process described in Section 2.2, equal numbers of mole (0.0176) of each reagent were added to the $\mathrm{AC}$, suck it in the reagent overnight and then carbonized again in the furnace at $600{ }^{\circ} \mathrm{C}$ for $1 \mathrm{~h}$ under $\mathrm{N}_{2}$ flow (i.e., post $\mathrm{N}$-treatment). Among these reagents, $\mathrm{U}$ gives the largest amount of $\mathrm{N}$ to our $\mathrm{Ch}-\mathrm{AC}$ and hence was selected as the $\mathrm{N}$ doping agent for the heavy metal removal study. For comparison proposes, a pre N-treatment method was studied too; this was done by first adding the $\mathrm{N}$ doping reagent to $\mathrm{Ch}$ and carbonizing it at $600{ }^{\circ} \mathrm{C}$ for $1 \mathrm{~h}$; after cooling the activators were added to the sample and directly carbonized again for $1 \mathrm{~h}$ at similar temperature.

\subsection{Characterization of $A C$ and N-Rich AC}

Nitrogen adsorption/desorption analysis $\left(77 \mathrm{~K} \& \mathrm{P} / \mathrm{P}_{0}=1\right)$ was performed using a Micromeritics ASAP 2020 sorptometer (Micromeritics, GA, USA). Before the analysis, the samples were degassed for $8 \mathrm{~h}$ at $200{ }^{\circ} \mathrm{C}$ under high vacuum. The Brunauer-Emmet-Teller (BET) equation [43], t-plot method [44], and the BJH analysis [45] were employed for calculating the surface area and porosity parameters. The AC and N-rich ACs surface morphology were assessed by: (a) SEM, (scanning electron microscopy JEOL JSM 5700, Tokyo, Japan), (b) FESEM, (field emission scanning electron microscope, LEO Supra 50VP, Carl Zeiss, Oberkochen, Germany). Infrared analysis was carried out using JASCO FTIR6300 spectrometer (JASCO, Tokyo, Japan). Samples were mixed with dry KBr and pressed into a pellet. The N-rich ACs were analyzed for their total carbon, hydrogen, and nitrogen content using CHN analysis, and this was carried out using UNICUBE elemental analyzer (Elementar UK Ltd., Stockport, UK) with acetanilide as a standard. Apparent density was determined using a standard method. The measurements were repeated three times for each sample and the average value was reported. The chemical structure of the surface of the N-rich ACs and their surface elemental composition were determined using $X$ ray photoelectron spectroscopy (XPS) analysis. The photoelectron spectra were recorded by means of Thermo ESCALAB 250 Xi spectrometer (Thermo Scientific, London, UK) using a monochromatic $\mathrm{Al} \mathrm{K} \alpha$ radiation $(1486.6 \mathrm{eV})$ source of $\mathrm{X}$-rays, with a spot size of $850 \mu \mathrm{m}$. The spectra acquisition and processing were carried out using the software Thermo Avantage, version v5.956 (accessed on November 2020). Thermogravimetric analysis (TGA) and differential thermal analysis (DTA) thermograms were performed using Mettler Toledo TGA 2 apparatus (Mettler-Toledo, Columbus, $\mathrm{OH}, \mathrm{USA}$ ). Heating was conducted under $\mathrm{N}_{2}$ with a flow rate of $100 \mathrm{~mL} / \mathrm{min}$ and a heating rate of $20^{\circ} \mathrm{C} / \mathrm{min}$ from room temperature to $1000{ }^{\circ} \mathrm{C}$.

\subsection{Adsorption Experiment}

This experiment was performed on sample $10 \mathrm{Ch} 600.60 \mathrm{~K}_{2} \mathrm{CO}_{3} . \mathrm{U}$. This sample was selected because it gives the largest surface area $\left(1556 \mathrm{~m}^{2} / \mathrm{g}\right)$ and largest amount of nitrogen (14\% by weight). The experiment was carried out by preparing aqueous solution of $\mathrm{Cr}(\mathrm{VI})$ and $\mathrm{Pb}$ (II) with different initial concentrations (Ci). This happened by dissolving the required amount of $\mathrm{CrO}_{3}$ or $\mathrm{Pb}\left(\mathrm{NO}_{3}\right)_{2}$ into deionized water to prepare 10, 15, 20, 30, 40, 50,60 , and $70 \mathrm{mg} / \mathrm{L}$ solutions of heavy metals. Different amounts of $\mathrm{AC}(2,5,10,15$ and $20 \mathrm{~g} / \mathrm{L}$ ) were used in order to check the removal efficiency of the prepared AC. For example, $0.5 \mathrm{~g}$ of $10 \mathrm{Ch} 600.60 \mathrm{~K}_{2} \mathrm{CO}_{3}$.U were added into $250 \mathrm{~mL} \mathrm{Cr}(\mathrm{VI})$ or $\mathrm{Pb}$ (II) solution which was then placed in a New Brunswick Scientific Co shaker (Edison, NJ, USA) at room temperature and $120 \mathrm{rpm}$ for one hour. The Experiment was done using both the AC with 
$\mathrm{N}_{2}$ enrichment and the $\mathrm{AC}$ without enrichment. The $\mathrm{pH}$ of the aqueous solution is known to significantly affect and control the adsorption process. According to this, different $\mathrm{pH}$ solutions were prepared (2 to 8 ), which were adjusted using either $\mathrm{KOH}$ and/or $\mathrm{HCl}$ solution. The $\mathrm{pH}$ value was measured using a Thermo Scientific Origin Star A111 pH meter (Waltham, Massachusetts, USA). The effect of $\mathrm{pH}$ on adsorption experiment was carried out as preliminary study to determine the suitable $\mathrm{pH}$ for adsorption of $\mathrm{Cr}(\mathrm{VI})$ and $\mathrm{Pb}$ (II) from aqueous solution. The samples final concentrations were measured using Pinnacle 900F atomic absorption spectroscopy (AAS) (Perkin Elmer, Waltham, MA, USA) and inductively coupled NEXION 350D plasma mass spectrometry (ICP-MS), (Perkin Elmer, Waltham, MA, USA).

Three isotherm models, i.e., Langmuir [46], Freundlich [47], and Temkin [48], were used to analyze the equilibrium $\mathrm{Cr}(\mathrm{VI})$ and $\mathrm{Pb}$ (II) uptake by prepared activated carbon. Using version 9.8 OriginPro 2021 software, (OriginLab Corporation, Northampton, MA, USA) (accessed on 7th of February 2021), the Langmuir, Freundlich, and Temkin isotherm parameters were determined using the non-linear forms to obtain their constants and their respective correlation coefficients. Full details of these models can be found elsewhere [49].

The adsorption kinetics is important in wastewater treatment because it controls the solute removal rate, which at the same time controls the residence time of solute uptake at the solid-liquid interface [50].

The adsorption kinetics process was tested for both $\mathrm{Cr}(\mathrm{VI})$ and $\mathrm{Pb}(\mathrm{II})$ removal. For the $\mathrm{Cr}(\mathrm{VI})$ removal, the studied time range was from $2 \mathrm{~min}$ to $96 \mathrm{~h}$. For $\mathrm{Pb}(\mathrm{II})$, however, the time interval was different due to the fast adsorption into the surface of the prepared AC; it varied from 2 to $60 \mathrm{~min}$. In this study, both pseudo-first and second order were applied using the following Equations:

$$
\begin{gathered}
q_{t}=q_{e}\left(1-\exp \left(-k_{\mathrm{pf}} \mathrm{t}\right)\right) \text { Pseudo }- \text { first }- \text { order equation } \\
q_{t}=q_{e}\left(\frac{k_{\mathrm{ps}} q_{e} \mathrm{t}}{1+k_{\mathrm{ps}} q_{e} \mathrm{t}}\right) \text { Pseudo }- \text { sec ond }- \text { order equation }
\end{gathered}
$$

The equation parameters are explained in the List of Symbol and Unit section. Both the correlation coefficient $\left(R^{2}\right)$ and reduced chi-square $\left(\chi^{2}\right.$, see Equation (3)) were used to analyze the error in the non-linear fits. The lower the $\chi^{2}$ values, the lower the difference between the model and the experimental data [31].

$$
\chi^{2}=\sum_{i=1}^{N} \frac{\left(q_{e}-q_{e, c a l}\right)^{2}}{q_{e, c a l}}
$$

where $N$ is the number of studied samples. The equation parameters are explained in the List of Symbols and Units section. Equation (3) is used to calculate $\chi^{2}$ for the isotherms, while for the kinetic models, $q_{\mathrm{e}}$ and $\mathrm{q}_{\mathrm{e}, \mathrm{cal}}$ are replaced by $q_{\mathrm{t}}$ and $\mathrm{q}_{\mathrm{t}, \mathrm{cal}}$.

Thermodynamics studies for the adsorption of $\mathrm{Cr}(\mathrm{VI})$ and $\mathrm{Pb}(\mathrm{II})$ on the surface of the $\mathrm{AC}$ at different initial concentration $(\mathrm{Ci}=10,15,20,30,40,50,60$, and $70 \mathrm{mg} / \mathrm{L})$ of chromium and lead, were studied at 5 different temperatures $\left(25,35,45,55\right.$, and $\left.65^{\circ} \mathrm{C}\right)$ under fixed values of $\mathrm{pH}$ (for $\mathrm{Cr}$, the $\mathrm{pH}$ was 2 while for $\mathrm{Pb}$ the $\mathrm{pH}$ was 6) and $\mathrm{AC}$ dose of $10 \mathrm{~g} / \mathrm{L} . \Delta \mathrm{G}$ values were calculated using Van 't Hoff equation using the Langmuir constant $\left(K_{\mathrm{L}}\right)$ for $\mathrm{CrVI}$ ) for $\mathrm{Pd}(\mathrm{II})$ removal after correcting the $K_{\mathrm{L}}$ unit by multiplying their values by a factor of 1000 and by the molecular weight and the unitary standard concertation of the adsorbate, with the assumption that the adsorbate solution is very dilute [51]. Then the enthalpy $(\Delta H)$ and the entropy $(\Delta S)$ of the adsorption processes were calculated from a plot of $\ln \left(K_{\mathrm{L}}{ }^{\text {corr }}\right)$ versus $1 / \mathrm{T}$. For all studies (isotherms, kinetics, and thermodynamics), the lowest concentration of heavy metal was used, because the procedure is known to be challenging and needs an efficient adsorbent [52].

A preliminary adsorption experiment was carried out on a real wastewater sample (obtained from an oil field). It was found that it contains the following metal ions: $\mathrm{Cr}$, As, 
$\mathrm{Ni}, \mathrm{Fe}, \mathrm{Cu}, \mathrm{Mn}, \mathrm{Mg}, \mathrm{Ca}, \mathrm{Ba}, \mathrm{Na}$, and $\mathrm{K}$ ions at the following concentrations, respectively: 23.0, 7.7, 23.7, 113.3, 4.3, 5.7, 2754.7, 13,144.7, 4.7, 73,793.3, and $5730.7 \mathrm{mg} / \mathrm{L}$. The adsorption experiment was performed at room temperature for $1 \mathrm{~h}$ using $10 \mathrm{Ch} 600.60 \mathrm{~K}_{2} \mathrm{CO}_{3} . \mathrm{U}$ as adsorbent.

All the adsorption experiments were repeated three times to ensure the repeatability and to assess the standard deviation around the average which were found to be too small (always less than $0.2 \%$ ). Errors are caused by measuring the mass of $\mathrm{AC}$ and the mass of the heavy metals. Using a five-digit balance, the estimated error for the mass of AC is $0.05 \%$ and for the lowest heavy metal concentration is $2 \%$. The solution preparations are also a source of errors but with using accurate volumetric flasks and pipettes, the errors were estimated to be $2 \%$. Hence, the worst total errors in this study are estimated to be of less than $\pm 4 \%$.

\section{Results and Discussion}

\section{1. $\mathrm{N}_{2}$ Sorptiometry}

The pore structure, surface area and porosity of the studied Ch-ACs were characterized by $\mathrm{N}_{2}$ sorptiometry. Figure $1 \mathrm{~A}$ presents the $\mathrm{N}_{2}$ adsorption-desorption isotherms of ChACs prepared with different activators $\left(\mathrm{K}_{2} \mathrm{CO}_{3}, \mathrm{KOH}\right.$ or $\left.\mathrm{Na}_{2} \mathrm{CO}_{3}\right)$, while Figure $1 \mathrm{~B}$ has a focus on the isotherms of $\mathrm{K}_{2} \mathrm{CO}_{3}$-activated $\mathrm{Ch}$ - $\mathrm{AC}$ when using different amount of $\mathrm{Ch}$ and activator. In Figure 1C, however, are compared the isotherms of the functionalized AC prepared by pre- and post-treatment methods. The specific parameters of all samples are summarized in Table 1. All the isotherms were found to be of Type I according to the IUPAC classifications [6]. Type I isotherm (concave toward the relative pressure $\left(\mathrm{P} / \mathrm{P}_{0}\right)$ axis and the adsorbed amount approaches a limiting value as $\mathrm{P} / \mathrm{P}_{0}$ approaches 1 ) often represents the sorption isotherms obtained on microporous materials [39]. All isotherms in Figure 1 initially increase rapidly with increasing pressure, which means that our procedures yield mostly microporous AC with pore size $d_{\mathrm{p}}<2$ (see Table 1 and the pore size distributions in Figure S1 in the Supplementary Materials). The nitrogen isotherm of the prepared $\mathrm{Ch}-\mathrm{ACs}$ also exhibits an almost horizontal plateau at high relative pressure, indicating micropore domination with little extent of mesopores $\left(2<d_{\mathrm{p}}<50 \mathrm{~nm}\right)$ on its surface. Another observation is that the curves of all samples shown in Figure 1A,B do not exhibit hysteresis which confirms microporosity with narrow pore size distribution (see also Figure S1). When using N-enrichment material (Figure 1C), the curve shows Type IV isotherms with narrow $\mathrm{H} 4$ hysteresis loop which is usually observed with samples containing narrow slit micropores and mesopores [3].

Table 1. Surface, pore volume, and pore size parameters of $\mathrm{Ch}-\mathrm{AC}$ prepared using the indicated activators and different $\mathrm{N}_{2}$ enrichment agents. All samples were subjected to $\mathrm{HCl}$ etching, except the AC with no activator.

\begin{tabular}{|c|c|c|c|c|c|c|c|c|c|}
\hline Sample & $\begin{array}{l}S_{\mathrm{BET}} a \\
\left(\mathrm{~m}^{2} / \mathrm{g}\right)\end{array}$ & $\begin{array}{c}S_{\text {micro }} b \\
\left(\mathrm{~m}^{2} / \mathrm{g}\right)\end{array}$ & $\begin{array}{c}S_{\text {meso }} \\
{ }^{c}\left(\mathrm{~m}^{2} / \mathrm{g}\right)\end{array}$ & $\begin{array}{c}S_{\text {meso }}+ \\
S_{\text {ext }} b \\
\left(\mathrm{~m}^{2} / \mathrm{g}\right)\end{array}$ & $\begin{array}{c}S_{\text {micro }} / S_{\text {BET }} \\
(\%)\end{array}$ & $\begin{array}{c}V_{\text {tot }}{ }^{a} \\
\left(\mathrm{~cm}^{3} / \mathrm{g}\right)\end{array}$ & $\begin{array}{l}V_{\text {micro }} b \\
\left(\mathrm{~cm}^{3} / \mathrm{g}\right)\end{array}$ & $\begin{array}{l}V_{\text {meso }} c \\
\left(\mathrm{~cm}^{3} / \mathrm{g}\right)\end{array}$ & $\begin{array}{l}d_{\mathrm{p}}{ }^{a} \\
(\mathrm{~nm})\end{array}$ \\
\hline 10Ch600 (no activator) & 57.8 & 30.9 & 15.4 & 26.8 & 53.5 & 0.033 & 0.014 & 0.019 & 2.3 \\
\hline $10 \mathrm{Ch} 600.60 \mathrm{CaCO}_{3}$ & 101.5 & 16.5 & 78.6 & 84.9 & 16.3 & 0.089 & 0.007 & 0.082 & 3.5 \\
\hline $10 \mathrm{Ch} 600.60 \mathrm{Na}_{2} \mathrm{CO}_{3}$ & 633.7 & 319.2 & 307.3 & 314.6 & 50.4 & 0.310 & 0.125 & 0.185 & 2 \\
\hline $10 \mathrm{Ch} 600.60 \mathrm{KOH}$ & 1346.6 & 1020.2 & 103.1 & 326.4 & 75.8 & 0.581 & 0.400 & 0.181 & 1.7 \\
\hline $10 \mathrm{Ch} 600.20 \mathrm{~K}_{2} \mathrm{CO}_{3}$ & 1556.0 & 977.8 & 254.5 & 578.5 & 62.8 & 0.691 & 0.375 & 0.316 & 1.8 \\
\hline $10 \mathrm{Ch} 600.60 \mathrm{~K}_{2} \mathrm{CO}_{3}$ & 1366.6 & 852.5 & 216.3 & 473.7 & 62.4 & 0.598 & 0.332 & 0.266 & 1.8 \\
\hline $5 \mathrm{Ch} 600.20 \mathrm{~K}_{2} \mathrm{CO}_{3}$ & 1087 & 600.8 & 226.9 & 486.5 & 55.0 & 0.512 & 0.231 & 0.281 & 1.9 \\
\hline $5 \mathrm{Ch} 600.60 \mathrm{~K}_{2} \mathrm{CO}_{3}$ & 905.5 & 701.3 & 62.5 & 83.9 & 77.5 & 0.402 & 0.275 & 0.128 & 1.8 \\
\hline $10 \mathrm{Ch} 600.60 \mathrm{~K}_{2} \mathrm{CO}_{3} . \mathrm{U}$ & 771.3 & 619.6 & 79.0 & 151.7 & 80.3 & 0.389 & 0.289 & 0.098 & 2.0 \\
\hline $10 \mathrm{Ch} 600.60 \mathrm{~K}_{2} \mathrm{CO}_{3} . \mathrm{HA}$ & 536.4 & 446.7 & 46.4 & 85.8 & 83.3 & 0.262 & 0.210 & 0.053 & 2.0 \\
\hline $10 \mathrm{Ch} 600.60 \mathrm{~K}_{2} \mathrm{CO}_{3} \cdot \mathrm{EA}$ & 400.4 & 341.1 & 34.2 & 59.3 & 85.0 & 0.204 & 0.160 & 0.043 & 2.0 \\
\hline $10 \mathrm{Ch} 600.60 \mathrm{~K}_{2} \mathrm{CO}_{3}$.DAP & 336.8 & 279.9 & 50.2 & 86.9 & 76.0 & 0.197 & 0.131 & 0.066 & 2.1 \\
\hline $10 \mathrm{Ch} 600.60 \mathrm{~K}_{2} \mathrm{CO}_{3} . \mathrm{DDA}$ & 319.1 & 229.8 & 52.3 & 89.3 & 72.0 & 0.170 & 0.107 & 0.061 & 2.1 \\
\hline $10 \mathrm{Ch} 600.60 \mathrm{~K}_{2} \mathrm{CO}_{3}$. DDAB & 306.1 & 201.9 & 40.9 & 104.1 & 66.0 & 0.160 & 0.093 & 0.067 & 2.1 \\
\hline $10 \mathrm{Ch} 600.60 \mathrm{~K}_{2} \mathrm{CO}_{3} \cdot \mathrm{A}$ & 85.8 & 51.9 & 19.1 & 34.4 & 60.5 & 0.050 & 0.024 & 0.026 & 2.3 \\
\hline
\end{tabular}

${ }^{a}$ BET specific surface area $\left(S_{\mathrm{BET}}\right)$, total pore volume determined at $\mathrm{p} / \mathrm{p}^{\circ}=0.9956\left(V_{\mathrm{tot}}\right)$, and adsorption average pore width $\left(d_{\mathrm{p}}\right)$.

${ }^{b}$ Determined using t-Plot method. ${ }^{c}$ BJH adsorption cumulative surface area $\left(S_{\text {micro }}\right)$ and volume $\left(V_{\text {meso }}\right)$ of pores between 2 and $50 \mathrm{~nm}$. 

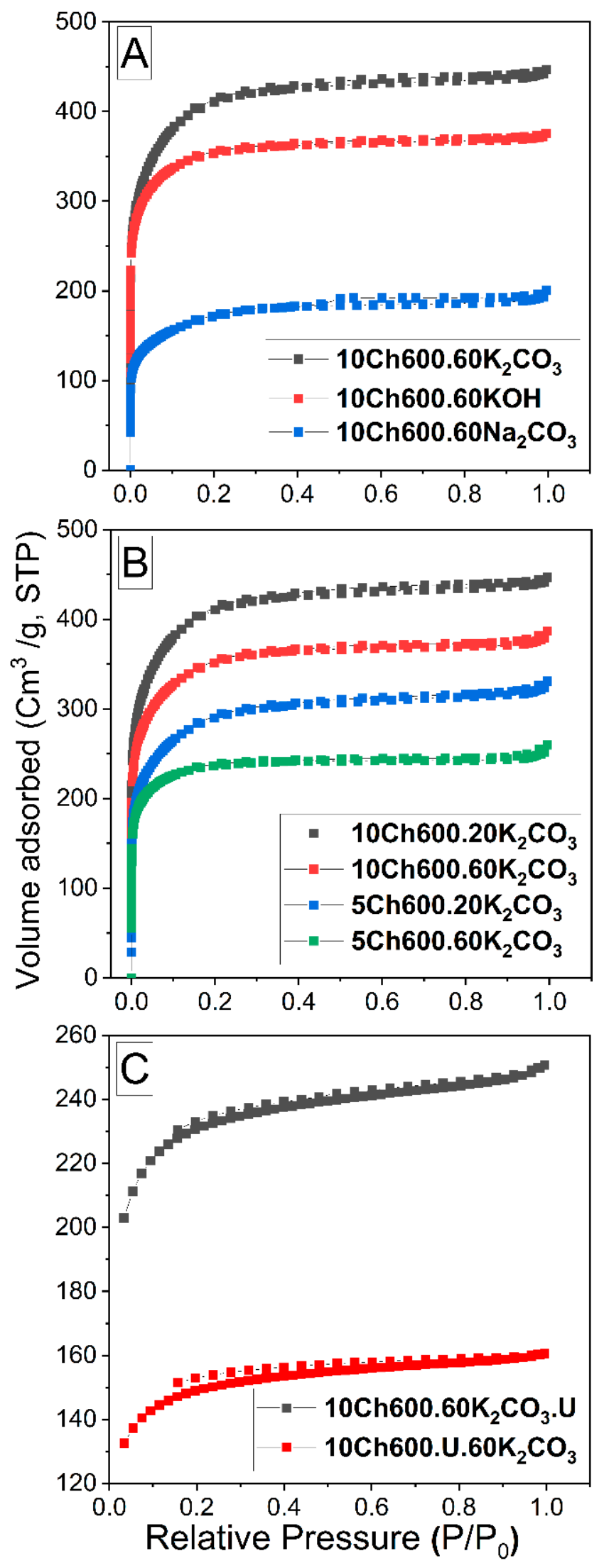

Figure 1. $\mathrm{N}_{2}$ adsorption-desorption isotherms (A) for Ch-AC with different activators, (B) for ChAC using $\mathrm{K}_{2} \mathrm{CO}_{3}$ as activator with different amount of activator and chitosan, and (C) for Ch-AC prepared with post- and pretreatment method using urea (U). 
The surface characteristics reported in Table 1 show clearly that using a $\mathrm{K}_{2} \mathrm{CO}_{3}$ activator gives much higher $S_{\mathrm{BET}}$ and $V_{\text {tot }}$ compared with $\mathrm{Na}_{2} \mathrm{CO}_{3}, \mathrm{CaCO}_{3}$, and $\mathrm{KOH}$. For example, the $S_{\mathrm{BET}}$ increased during the activation process from $57.8 \mathrm{~m}^{2} / \mathrm{g}$ for $\mathrm{Ch}-\mathrm{AC}$ (no activator) to $633.7 \mathrm{~m}^{2} / \mathrm{g}$ when using $\mathrm{Na}_{2} \mathrm{CO}_{3}$ activator and reached $1556 \mathrm{~m}^{2} / \mathrm{g}$ upon employing $\mathrm{K}_{2} \mathrm{CO}_{3}$ as activator. Such an increase in $S_{\mathrm{BET}}$ value for $\mathrm{K}_{2} \mathrm{CO}_{3}$-activated $\mathrm{Ch}-\mathrm{AC}$ is caused by its higher degree of reactivity [5]. It is worth noticing here that $\mathrm{K}_{2} \mathrm{CO}_{3}$-activated $\mathrm{Ch}-\mathrm{AC}$ results in a high degree of both micro- and mesoporosity $\left(V_{\text {micro }}=0.375\right.$ and $V_{\text {meso }}=0.316 \mathrm{~cm}^{3} / \mathrm{g}$ ). Table 1 . It also reveals that the addition of N-enrichment materials decreased $S_{\mathrm{BET}}$ and $V_{\text {tot }}$ for the treated Ch-ACs. This is partially due to the fact that the chemically bonded functional groups on the carbon surface block or limit the access for nitrogen molecules to some active sites [22] but it is also due to the second thermal treatment of the prepared doped-AC. Compared to other sources of $\mathrm{N}$, using $\mathrm{U}$ as N-enrichment material gives the highest $S_{\mathrm{BET}}$ (see Table 1) and the largest amount of $\mathrm{N}$, and this is related to the fact that such low molecular weight hydrophilic molecules contains two $\mathrm{N}$ atoms per molecule, as well as a $\mathrm{C}=\mathrm{O}$ functional group [22]. Comparing the pretreatment method to the post-treatment method (see Figure $1 \mathrm{C}$ and Table 1), it is clear that the post-treatment method gives a greater surface area and more porous structure. It is believed that such behavior is due to the blockage of the pores when AC is pretreated before activation.

\subsection{SEM and FESEM}

The morphology and structure of the Ch-based ACs and N_enriched Ch-ACs before and after the removal of heavy metal were characterized using SEM and FESEM. SEM micrographs of ACs are presented in Figure 2A-H. In general, carbon surfaces were of irregular shapes and there was a presence of macropores of different sizes and shapes. Figure 2A represents pure Ch-based ACs without any use of activator (sample 10Ch600); it is almost a nonporous surface which is reflected on its $S_{\mathrm{BET}}$ (Table 1). Similar to pure $\mathrm{Ch}-\mathrm{AC}, \mathrm{Ch}-\mathrm{AC}$ prepared with $\mathrm{Na}_{2} \mathrm{CO}_{3}$ activator (no $\mathrm{HCl}$ etching) shows no macroporosity (Figure 2B) while $\mathrm{HCl}$-etched samples show the development of such pores (Figure 2C) (the etching opens cavities in the structure due to the removal of the $\mathrm{Na}^{+}$ions) [20]. Using other activators such as $\mathrm{KOH}$ (Figure 2D) and $\mathrm{K}_{2} \mathrm{CO}_{3}$ (Figure 2E) with $\mathrm{HCl}$ etching resulted in a clear generation of macropores and even smaller pores that are beyond the resolution of SEM. Such observations go hand-in-hand with the $\mathrm{N}_{2}$ sorptiometry results reported in Table 1 . The SEM image of $10 \mathrm{Ch} 600.60 \mathrm{~K}_{2} \mathrm{CO}_{3}$ (AC with the highest obtained $S_{\mathrm{BET}}$ and $V_{\text {tot }}$ ) are shown in Figure 2E, where the image shows a clear development of porosity.

A well-developed porous surface was observed in the FESEM images in Figure $2 \mathrm{~F}-\mathrm{H}$ (all are activated with $\mathrm{K}_{2} \mathrm{CO}_{3}$ ). The image in Figure $2 \mathrm{~F}$ refers to $\mathrm{AC}$ activated with a larger amount of $\mathrm{K}_{2} \mathrm{CO}_{3}(60 \mathrm{~mL}, 0.0176 \mathrm{~mol})$, while the less porous images shown in Figure $2 \mathrm{G}$ is for $\mathrm{AC}$ functionalized using U. Finally, the morphology of $\mathrm{Ch}-\mathrm{AC}$ after $\mathrm{Cr}(\mathrm{VI})$ removal is shown in Figure $2 \mathrm{H}$. Before the adsorption, the $\mathrm{Ch}-\mathrm{AC}$ surface was rough, porous, and irregular, but after $\mathrm{Cr}(\mathrm{VI})$ removal, the roughness and the pores on the surface decreased. This change confirms the adsorption of $\mathrm{Cr}(\mathrm{VI})$ ions on the $\mathrm{Ch}-\mathrm{ACs}$.

\subsection{Structural and Compositional Studies}

\subsubsection{X-ray Photoelectron Spectroscopy (XPS)}

This analysis was carried out in order to assess the surface chemical composition of the Ch-ACs. Table 2 reports the atomic surface concentration values obtained from this analysis. The main elements in the samples are $\mathrm{C}, \mathrm{O}$, and $\mathrm{N}$. It was found that by varying the amount of $\mathrm{Ch}$ and the activator, the $\mathrm{N}$ atomic percent increases with increasing the $\mathrm{Ch}$ amount; this is because of $\mathrm{Ch}$ itself containing nitrogen in its structure. However, increasing the amount of activator might block some sites in the AC and result in less surface nitrogen, in our case, a slight difference in the amount of $\mathrm{N}$ was observed by changing the volume of activator, see Table 2 (the activator volume is mentioned in the terminology before the activator chemical formula). 


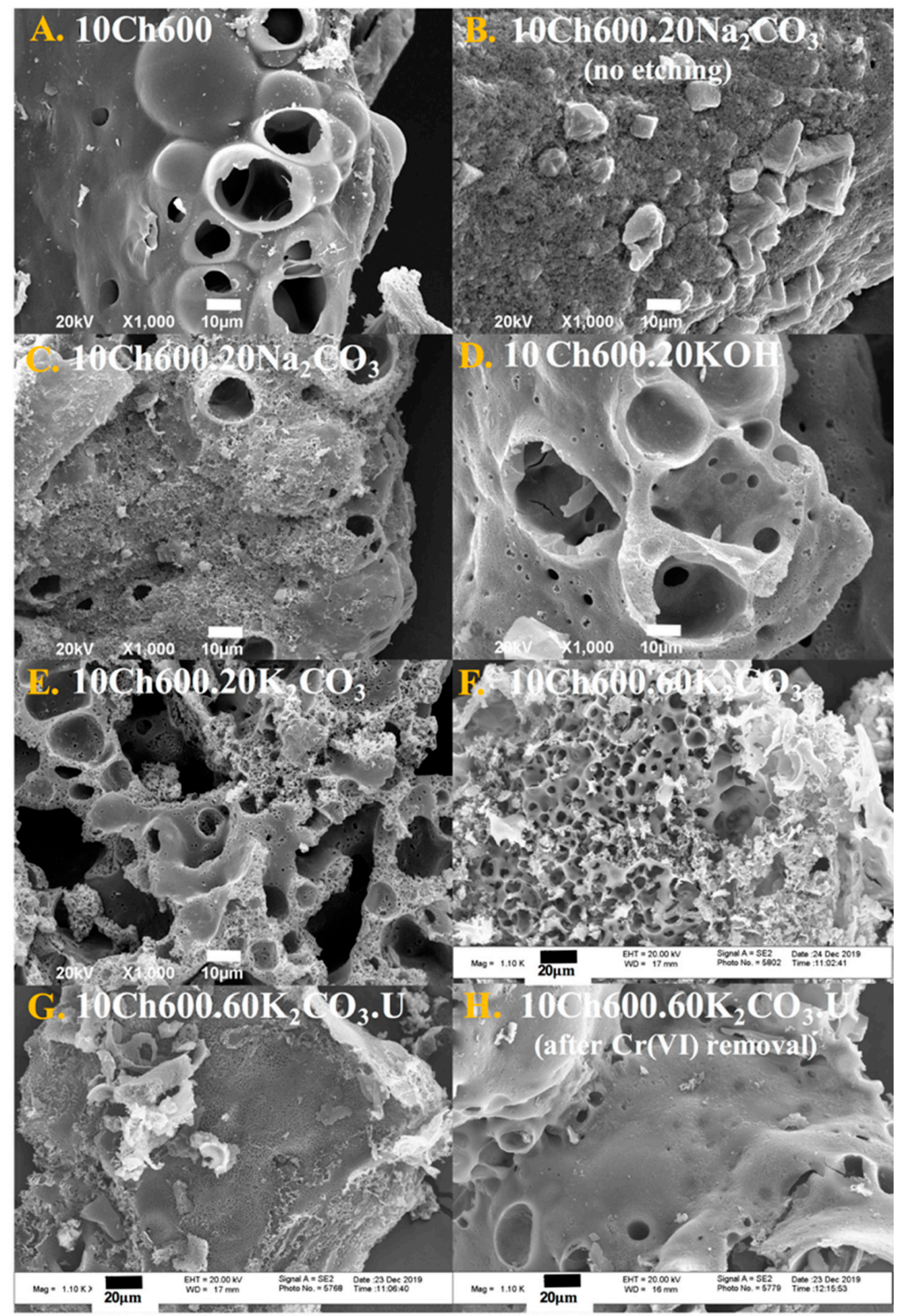

Figure 2. SEM (A-E) and FESEM (F-H) micrographs of AC samples, as indicated.

It was found that the functionalization procedure using $U$ gives the largest XPSdetermined amount of nitrogen (12.3 atomic\%) compared to other nitrogen-rich dopants. The smallest amount of nitrogen was 3.3 atomic\% when using DDA as N dopant (the same value of pure $\mathrm{Ch}-\mathrm{AC}$ ). The XPS elemental analysis were carried out also for the AC when the functionalizing done as a pretreatment and post-treatment method (Table 2).

Like the $S_{\mathrm{BET}}$ and porosity (see Section 3.1), the XPS results confirm that nitrogen content also more in the posttreatment preparation. 
Table 2. Surface (XPS) and bulk (CHN) elemental composition of chitosan-based AC with different activators and a different functional group for $\mathrm{N}$ enrichment.

\begin{tabular}{|c|c|c|c|c|c|c|c|}
\hline \multirow{2}{*}{ Sample } & \multicolumn{3}{|c|}{ XPS (Atomic\%) } & \multicolumn{4}{|c|}{ Elemental Analysis (wt $\%$ ) } \\
\hline & $\mathrm{C}$ & $\mathbf{N}$ & $\mathbf{O}$ & $\mathrm{C}$ & $\mathbf{H}$ & $\mathbf{N}$ & $\mathrm{O}^{\mathrm{a}}$ \\
\hline $\mathrm{Ch}$ & 70.4 & 3.3 & 24.0 & 40.1 & 7.8 & 7.8 & 44.3 \\
\hline \multicolumn{8}{|c|}{ Carbonization only } \\
\hline Ch600 & 74.7 & 4.2 & 15.6 & 72.3 & 1.2 & 7.5 & 19.0 \\
\hline \multicolumn{8}{|c|}{ Carbonization + Posttreatment with $\mathrm{N}$ agent } \\
\hline 10Ch600.U & 78.9 & 12.3 & 8.8 & 70.8 & 1.5 & 16.1 & 11.6 \\
\hline \multicolumn{8}{|c|}{ Carbonization + Activation } \\
\hline $10 \mathrm{Ch} 600.60 \mathrm{CaCO}_{3}$ & 64.0 & 4.1 & 24.9 & 68.2 & 1.2 & 6.1 & 24.5 \\
\hline $10 \mathrm{Ch} 600.60 \mathrm{KOH}$ & 42.5 & 3.5 & 40.2 & 52.4 & 2.3 & 2.6 & 42.7 \\
\hline $5 \mathrm{Ch} 600.20 . \mathrm{Na}_{2} \mathrm{CO}_{3}$ & 64.3 & 4.4 & 28.3 & 57.4 & 2.6 & 6.3 & 33.7 \\
\hline 10Ch600.20. $\mathrm{Na}_{2} \mathrm{CO}_{3}$ & 79.9 & 5.7 & 12.6 & 63.4 & 1.8 & 8.1 & 26.7 \\
\hline $5 \mathrm{Ch} 600.60 . \mathrm{Na}_{2} \mathrm{CO}_{3}$ & 76.3 & 4.4 & 19.3 & 49.7 & 1.3 & 4.4 & 44.6 \\
\hline 10Ch600.60. $\mathrm{Na}_{2} \mathrm{CO}_{3}$ & 77.1 & 4.9 & 17.9 & 65.8 & 1.3 & 8.5 & 24.4 \\
\hline $5 \mathrm{Ch} 600.20 . \mathrm{K}_{2} \mathrm{CO}_{3}$ & 64.3 & 4.0 & 25.3 & 54.3 & 2.3 & 2.9 & 40.5 \\
\hline $10 \mathrm{Ch} 600.20 . \mathrm{K}_{2} \mathrm{CO}_{3}$ & 69.0 & 3.6 & 21.0 & 56.5 & 3.3 & 3.9 & 36.3 \\
\hline $5 \mathrm{Ch} 600.60 . \mathrm{K}_{2} \mathrm{CO}_{3}$ & 60.4 & 3.6 & 29.3 & 51.5 & 1.2 & 4.2 & 43.1 \\
\hline $10 \mathrm{Ch} 600.60 . \mathrm{K}_{2} \mathrm{CO}_{3}$ & 70.0 & 4.3 & 19.8 & 63.6 & 2.3 & 6.5 & 27.6 \\
\hline \multicolumn{8}{|c|}{ Carbonization + Activation + Posttreatment with $\mathrm{N}$ agent } \\
\hline $10 \mathrm{Ch} 600.60 \mathrm{~K}_{2} \mathrm{CO}_{3} \cdot \mathrm{U}$ & 77.6 & 7.0 & 13.7 & 64.6 & 1.4 & 14.0 & 20.0 \\
\hline $10 \mathrm{Ch} 600.60 \mathrm{~K}_{2} \mathrm{CO}_{3} . \mathrm{HA}$ & 81.7 & 4.4 & 10.4 & 71.2 & 2.3 & 4.8 & 21.7 \\
\hline $10 \mathrm{Ch} 600.60 \mathrm{~K}_{2} \mathrm{CO}_{3} . \mathrm{EA}$ & 82.3 & 4.0 & 10.9 & 65.5 & 1.5 & 8.4 & 24.6 \\
\hline $10 \mathrm{Ch} 600.60 \mathrm{~K}_{2} \mathrm{CO}_{3} . \mathrm{DP}$ & 84.4 & 5.4 & 8.4 & 70.1 & 2.1 & 5.9 & 21.9 \\
\hline $10 \mathrm{Ch} 600.60 \mathrm{~K}_{2} \mathrm{CO}_{3} . \mathrm{DDA}$ & 92.4 & 3.3 & 4.3 & 76.4 & 2.5 & 4.9 & 16.2 \\
\hline $10 \mathrm{Ch} 600.60 \mathrm{~K}_{2} \mathrm{CO}_{3}$.DDAB & 89.2 & 3.7 & 6.1 & 79.4 & 0.6 & 5.1 & 14.9 \\
\hline $10 \mathrm{Ch} 600.60 \mathrm{~K}_{2} \mathrm{CO}_{3} \cdot \mathrm{A}$ & 89.1 & 6.5 & 4.4 & 71.9 & 0.9 & 7.5 & 19.7 \\
\hline \multicolumn{8}{|c|}{ Carbonization + Activation + Pretreatment with $\mathrm{N}$ agent } \\
\hline 10Ch600.U.60K ${ }_{2} \mathrm{CO}_{3}$ & 72.0 & 7.3 & 17.9 & 65.4 & 1.4 & 11.1 & 22.1 \\
\hline 10Ch600.HA. $60 \mathrm{~K}_{2} \mathrm{CO}_{3}$ & 68.5 & 4.8 & 22.9 & 68.3 & 1.3 & 9.1 & 21.3 \\
\hline 10Ch600.EA. $60 \mathrm{~K}_{2} \mathrm{CO}_{3}$ & 72.0 & 4.6 & 22.0 & 71.2 & 2.7 & 10.9 & 15.2 \\
\hline
\end{tabular}

Figure 3 represents the surface, $\mathrm{C} 1 \mathrm{~s}$, and N1s spectra for the $\mathrm{AC}$ used with and without $\mathrm{U}$ enrichments. For the $10 \mathrm{Ch} 600.60 . \mathrm{K}_{2} \mathrm{CO}_{3}$ sample, the $\mathrm{C} 1 \mathrm{~s}$ spectrum main peak at $284.6 \mathrm{eV}$ corresponding to $\mathrm{sp}^{2} \mathrm{C}(\mathrm{C}=\mathrm{C})$ and $\mathrm{sp}^{3}(\mathrm{C}-\mathrm{C})$ suggests that the largest number of $\mathrm{C}$ atoms were arranged in a conjugated honeycomb lattice $[19,22,53]$. The three small peaks at 285.9 , 287.0, and $288.4 \mathrm{eV}$ correspond to different bonding structure of the C-N/C-C and/or C-O bonds, and this is attributed to $\mathrm{N}-\mathrm{sp}^{2}, \mathrm{C}-\mathrm{O}-\mathrm{C}$, and N-sp ${ }^{3}$ bonds, respectively. According to the literature data, the bands $(285.3-286.3 \mathrm{eV})$ can be designated to phenolic, alcoholic, and etheric groups. Whereas, $287.2-287.9 \mathrm{eV}$ is designated to carbonyls, quinones, and nitrogen-bearing functionalities [22]. In the N1s spectrum of the same sample, only two peaks appeared, which can be assigned to pyridinic $\mathrm{N}(\mathrm{N}-6,398.3 \mathrm{eV})$ and pyrrolic $\mathrm{N}$ which is associated with phenolic or carbonyl groups on the surrounding carbon atoms (N-5, $400.1 \mathrm{eV}$ ) [15,54]. After addition of $\mathrm{U}$ (sample $10 \mathrm{Ch} 600.60 \mathrm{~K}_{2} \mathrm{CO}_{3} \cdot \mathrm{U}$ ), one peak disappeared from the $\mathrm{C} 1 \mathrm{~s}$ spectrum and a new peak appear in the N1s spectrum. The third peak in the N1s spectrum corresponds to the quaternary-type nitrogen, which is bonded to three atoms in the central, hollow site of the graphene layer, pyrrolic $\mathrm{N}$, or pyridonic $\mathrm{N}(\mathrm{N}-\mathrm{Q}$, $401.0 \mathrm{eV})[15,22]$. 

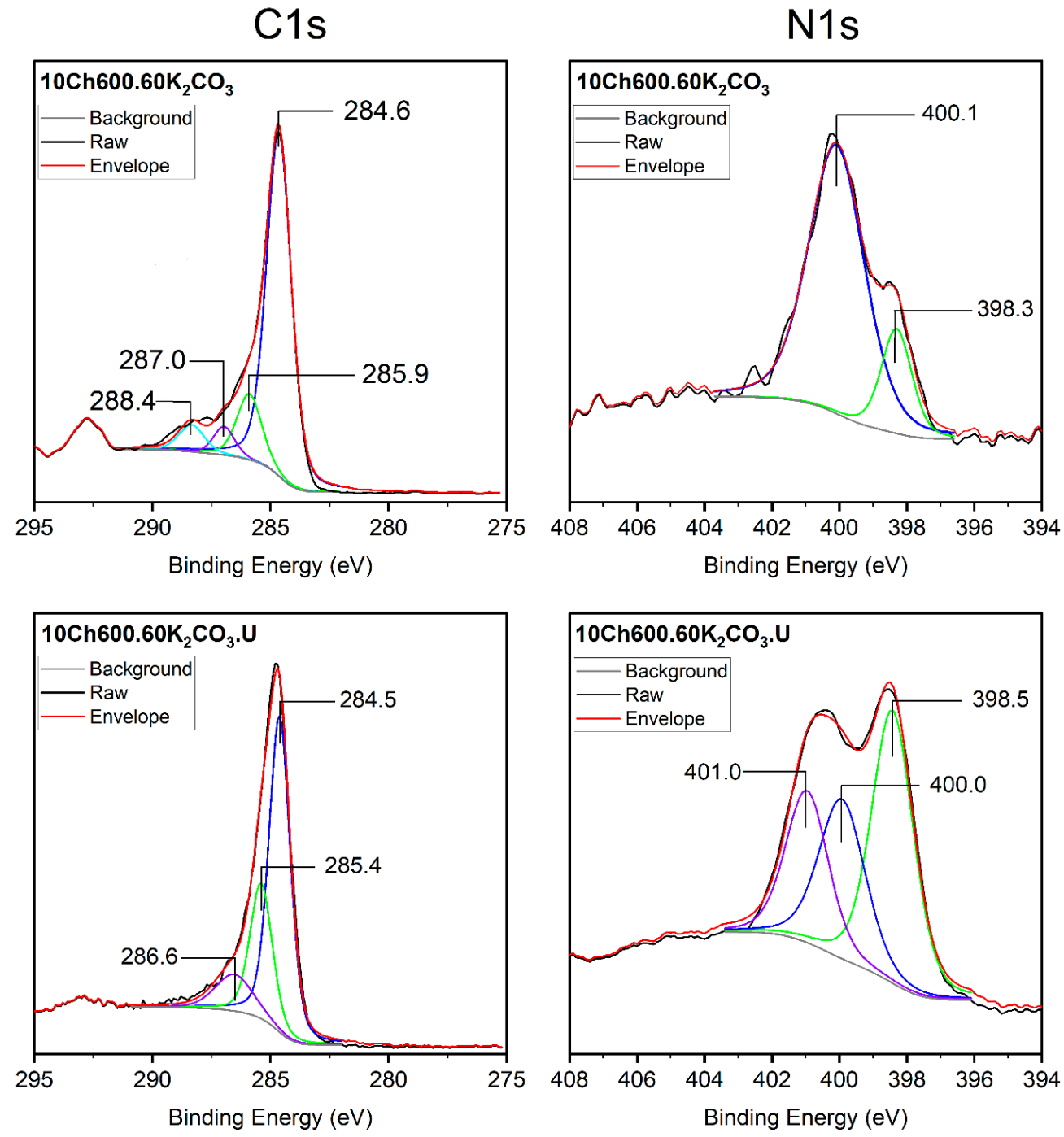

Figure 3. XPS C1s (left) and N1s (right) of Ch-based AC before and after functionalization with urea. Gray lines are the non-linear 'Smart Backgrounds' as been determined by the XPS instrument software, black lines are the raw data spectrum, and red lines are the reproduced envelope for the transition.

\subsubsection{Elemental Analysis (CHN)}

The $\mathrm{CHN}$ analyses were employed in this work to determine the bulk compositions of the studied Ch-ACs (i.e., total amount of carbon, hydrogen, and nitrogen contents). Detailed chemical contents of the Ch-AC and the N-rich Ch-AC (pre- and posttreatment preparation) are shown in Table 2. Firstly, one can see that the elemental analyses are in good agreement with that of XPS. For example, for pre-N enrichment, all the studied samples exhibit high $\mathrm{N}$ content which ranges from 2.5 to $8.5 \mathrm{wt} \%$ and after enrichment with $\mathrm{U}$, the amount of $\mathrm{N}$ reached as high as $16 \mathrm{wt} \%$. In general, many scientists found that using $\mathrm{U}$ as an $\mathrm{N}$-rich compound leads to ACs having 2- to 3-fold greater $\mathrm{N}$ content than samples prepared without $U$ which is also the case in this study [22]. By converting the $\mathrm{CHN}$ weight $\%$ to atomic $\%$ values, especially in the case of the pre- and post-treatment method, the CHN-determined N content is found to be higher than that of the XPS (i.e., the $\mathrm{N}$ content in the bulk is slightly more if compared to that of the outer surfaces).

\subsection{FTIR Analysis of Adsorbents}

The functional groups of $\mathrm{Ch}$ and $\mathrm{Ch}$-based $\mathrm{ACs}$ with $\mathrm{N}$ enrichments and their interactions were determined using FTIR analysis. Figure S2 shows the chitosan FTIR spectrum 
and the observed beaks were explained also in the supplementary information. The FTIR spectra of the chemically activated and N-enriched AC are shown in Figure 4. The spectrum of the adsorbents showed a band at $3408 \mathrm{~cm}^{-1}$ indicating the presence of hydroxyl groups and/or -NH [55]. The peaks in the region around $1557 \mathrm{~cm}^{-1}$ (present in all spectra) corresponds to the stretching vibration of carbonyl $(\mathrm{C}-\mathrm{O})$, carboxyl $(\mathrm{C}=\mathrm{O})$, and / or primary amine $(-\mathrm{NH})$ [16]. Whereas, the small peaks in the range of $2850-2916 \mathrm{~cm}^{-1}$ predict the symmetrical and asymmetrical $\mathrm{C}-\mathrm{H}$ stretching vibration of alkanes group [3]. The peaks which appeared for all adsorbents in the region of $1091 \mathrm{~cm}^{-1}$ represents the $\mathrm{C}-\mathrm{N}$ starching vibration. Figure S3 compares the spectrum of the used $\mathrm{Ch}$-based $\mathrm{AC}$ and the spectra after removal of $\mathrm{Cr}(\mathrm{VI})$ and $\mathrm{Pb}(\mathrm{II})$ ions. It was noticed that the position and the intensity of the hydroxyl group and carbonyl groups changed after adsorption. The peaks at $1096 \mathrm{~cm}^{-1}$, which correspond to $\mathrm{C}-\mathrm{N}$, are weaned and shifted to a higher wavelength, which confirms the adsorption. On the other hand, the peak at $3396 \mathrm{~cm}^{-1}$ (refer to $\mathrm{OH}$ and $\mathrm{N}-\mathrm{H}$ groups) are totally disappeared after the heavy metal removal (see Figure S3). The reasonable explanation is that these functional groups interacted with the heavy metal ions. This means also that the nitrogen functional group has an important role in the adsorption of the heavy metal ions.

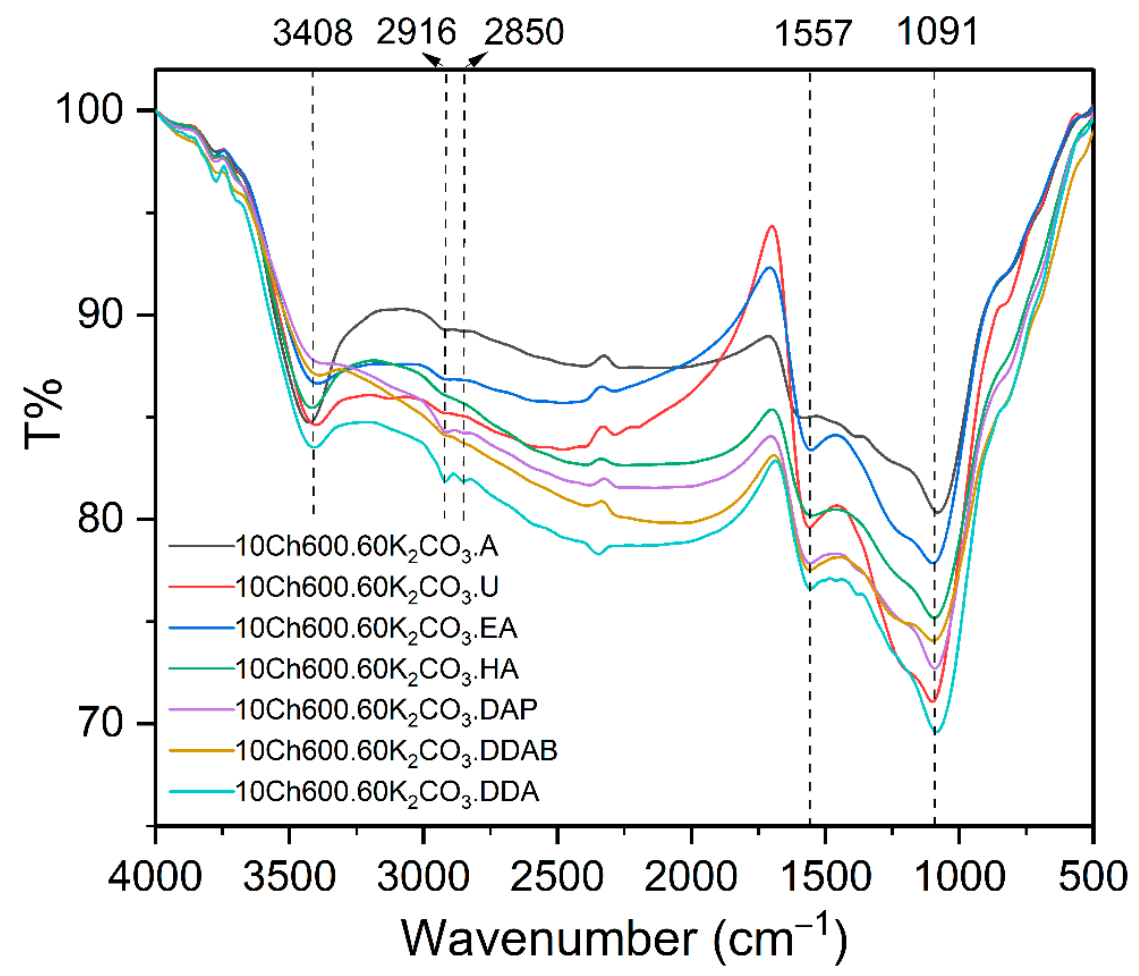

Figure 4. FTIR-spectrum of activated carbon using $\mathrm{K}_{2} \mathrm{CO}_{3}$ as activator and different $\mathrm{N}$-rich functional groups as indicated.

\subsection{TGA and DTA}

The thermogravimetric analysis (TGA) and the differential thermal analysis (DTA) thermograms of $\mathrm{Ch}$ under air and $\mathrm{N}_{2}$ are presented in Figure $\mathrm{S} 4$ while those for $\mathrm{Ch}$-based AC using both $\mathrm{Na}_{2} \mathrm{CO}_{3}$ and $\mathrm{K}_{2} \mathrm{CO}_{3}$ are shown in Figure 5. From Figure S4, one can see that the weight loss of $\mathrm{Ch}$ occurred in the temperature range of 30 to $550{ }^{\circ} \mathrm{C}$. Up to $600{ }^{\circ} \mathrm{C}$ there are three stages of evolution which are assigned to dehydration, decomposition, and carbonization. The TGA graph shows, up to $600{ }^{\circ} \mathrm{C}$, a total weight loss of about $70.6 \%$. The first observed weight loss occurred up to $150{ }^{\circ} \mathrm{C}$ and was of $11.6 \%$; this is due to the loss of physisorbed water. The second weight loss of $46.4 \%$ occur between 220 and $380{ }^{\circ} \mathrm{C}$ and referred to the decomposition of $\mathrm{Ch}$ and devolatilization of its components. The third stage was between 400 to $550{ }^{\circ} \mathrm{C}$, where up to $12.6 \%$ of weight loss was seen and this is due to the carbonization (formation of aromatic structure and functional groups). Above $600{ }^{\circ} \mathrm{C}$ 
and up to $1000{ }^{\circ} \mathrm{C}$, the weight of the sample was almost constant, designating that the basic structure of the carbon is established. Figure 5 represents the TGA and DTA analysis of Ch-ACs using $\mathrm{Na}_{2} \mathrm{CO}_{3}$ and $\mathrm{K}_{2} \mathrm{CO}_{3}$ activators, the total weight loss was less than that of pure $\mathrm{Ch}$ (see Figure S4). Up to $600{ }^{\circ} \mathrm{C}$, the observed weight loss of ACs prepared using $\mathrm{Na}_{2} \mathrm{CO}_{3}$ was $52.1 \mathrm{wt} \%$ while when using $\mathrm{K}_{2} \mathrm{CO}_{3}$, the loss was $45.6 \mathrm{wt} \%$, both of which consist of four stages, as indicated in the figure. The weight loss amounts of stages 1-3 are: 11.1, 25.9, 15.1 for $\mathrm{Na}_{2} \mathrm{CO}_{3}$-activated $\mathrm{AC}$ (Figure 5A) and 6.7, 27.0, 11.9 for $\mathrm{K}_{2} \mathrm{CO}_{3}$ activated ACs (Figure 5B). The stage marked (4) is a continuation of the carbonization process observed after stage (3). It is worth mentioning here the break in the TGA results at $600{ }^{\circ} \mathrm{C}$ was carried out intentionally to mimic the thermal treatment process employed in this study. The large endothermic peak observed in the DTA thermogram for both samples correspond to the weight loss during stage (2) which is the largest drop in weight among all the three stages.
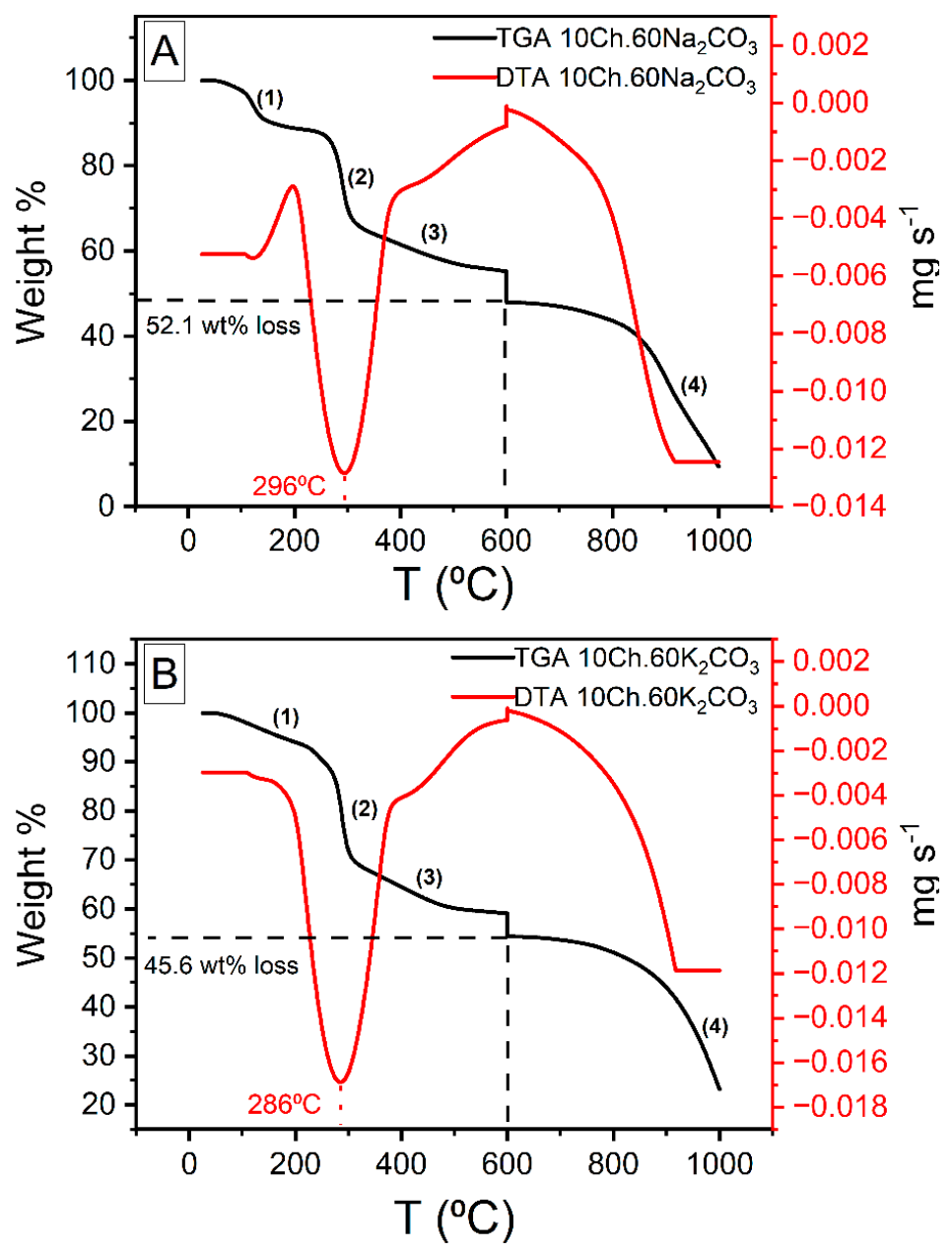

Figure 5. Thermogravimetric analysis of chitosan-based activated carbon (A): $\mathrm{Na}_{2} \mathrm{CO}_{3}$ activator, (B): $\mathrm{K}_{2} \mathrm{CO}_{3}$ activator) performed under nitrogen environment. The break at $600{ }^{\circ} \mathrm{C}$ was carried out intentionally to simulate the experimental process of the carbonation.

\subsection{Adsorption Properties of N-Rich Ch-Based AC 3.6.1. Effect of $\mathrm{pH}$}

The $\mathrm{pH}$ value of the solution plays an important role in the adsorption process. It can affect the surface charge of the adsorbent, the chemical nature of metallic cations, and the degree of ionization of an adsorbate molecule, and finally the efficiency of the heavy metal removal. The $\mathrm{Cr}(\mathrm{VI})$ removal was studied in the $\mathrm{pH}$ range of $2-8$, while the removal of $\mathrm{Pb}$ (II) in the range of $2-7$ (with higher $\mathrm{pH}$, the lead nitrate was only partially dissolved in 
the aqueous solution [41]). The study was done at initial $\mathrm{Cr}(\mathrm{VI})$ and $\mathrm{Pb}$ (II) concentrations of $10 \mathrm{mg} / \mathrm{L}$ and AC dosage of $10 \mathrm{~g} / \mathrm{L}$. To have high removal efficiency and high adsorption, the ionization charge of the adsorbate (here heavy metal ions, $\mathrm{Cr}(\mathrm{VI})$ and $\mathrm{Pb}(\mathrm{II})$ ) and the surface charge of the adsorbent (Ch-based AC) should be the opposite [56,57]. The adsorption of $\mathrm{Cr}(\mathrm{VI})$ was best at $\mathrm{pH}$ of 2 (see Figure $6 \mathrm{~A}$ ), and with increasing the $\mathrm{pH}$ of the solution, the adsorption decreased. This behavior can be attributed to the metal ions' behavior in the solution as well as to the AC surface functional groups. The mechanisms of $\mathrm{CrO}_{3}$ in the solution are as follows:

$$
\begin{aligned}
& \mathrm{CrO}_{3}+\mathrm{H}_{2} \mathrm{O} \rightarrow \mathrm{H}_{2} \mathrm{CrO}_{4} \\
& \mathrm{H}_{2} \mathrm{CrO}_{4} \leftrightharpoons \mathrm{H}^{+}+\mathrm{HCrO}_{4}{ }^{-} \\
& \mathrm{HCrO}_{4}{ }^{-} \leftrightharpoons \mathrm{H}^{+}+\mathrm{CrO}_{4}{ }^{2-}
\end{aligned}
$$
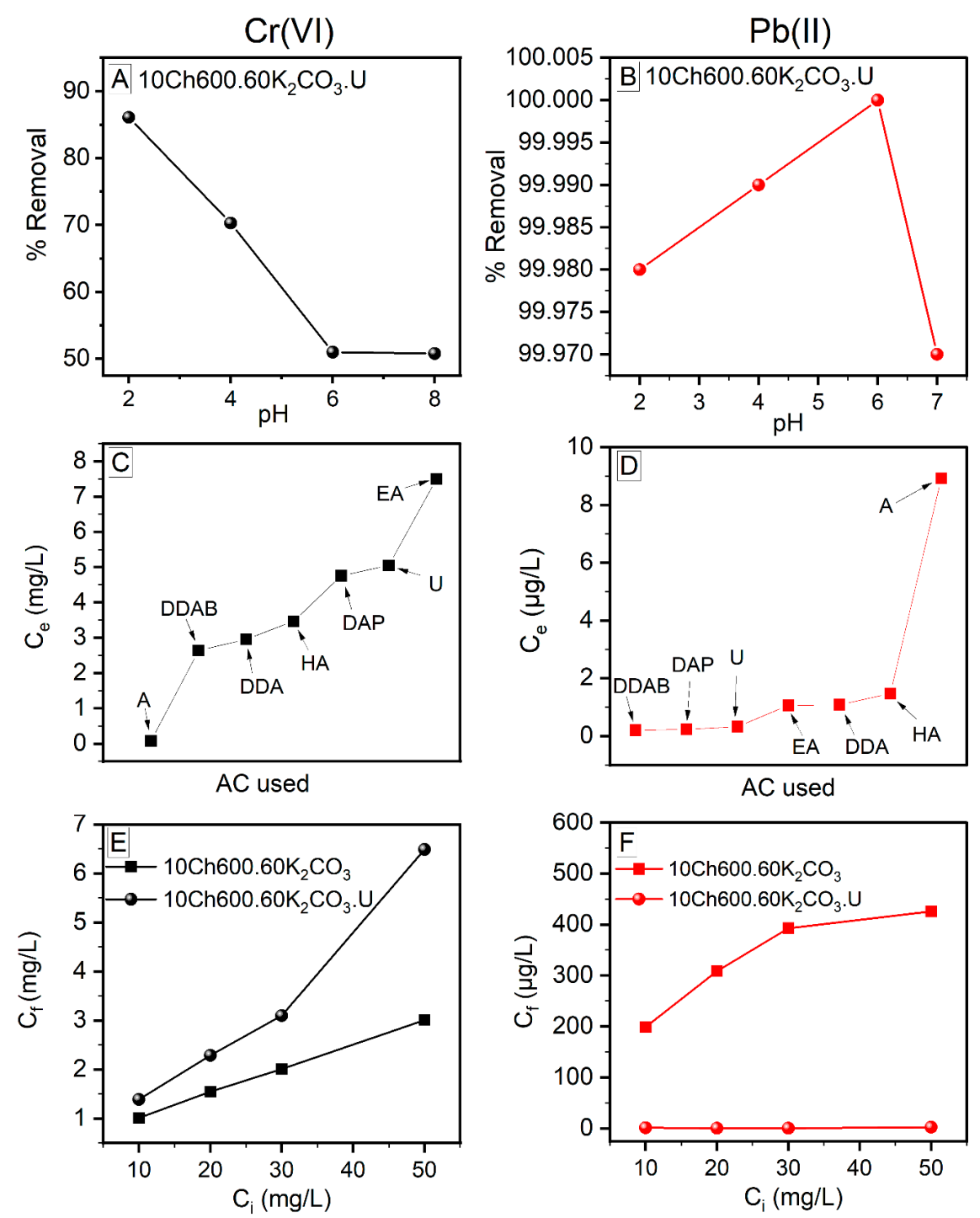

Figure 6. The behavior of $\mathrm{Cr}(\mathrm{VI})$ (Left) and $\mathrm{Pb}(\mathrm{II})$ (Right) ion removal with different parameters (explained in the List of Symbols and Units section). (A,B): Effect of $\mathrm{pH}$ on the removal efficiency of heavy metals; (C,D): Effect of different $\mathrm{N}$ enrichment reagents on the concentration of heavy metals at equilibrium; $(\mathbf{E}, \mathbf{F})$ : Comparison of the initial concentration of the heavy metals and their corresponding final concentration remained after the adsorption process. Conditions: AC dose: $10 \mathrm{~g} / \mathrm{L}$; the contact time: $1 \mathrm{~h}$; T: $25^{\circ} \mathrm{C}$; $\mathrm{Cr}(\mathrm{VI})$ and $\mathrm{Pb}$ (II) Ci: $10 \mathrm{mg} / \mathrm{L}$ (A-D); and $\mathrm{Cr}(\mathrm{VI}) \mathrm{pH}: 2, \mathrm{~Pb}(\mathrm{II})$ pH: $6(\mathbf{C}-\mathbf{F})$. 
In acidic media, the $\mathrm{Cr}(\mathrm{VI})$ ions exist as anions $\left(\mathrm{HCrO}_{4}{ }^{-}\right.$and $\left.\mathrm{CrO}_{4}{ }^{2-}\right)$ and the surface of the $\mathrm{AC}$ is protonated (have positive charge) which is highly recommended for $\mathrm{Cr}(\mathrm{VI})$ removal. The highly positive charge of the surface of $\mathrm{AC}$ strengthen the electrostatic forces between the $\mathrm{AC}$ and the $\mathrm{Cr}(\mathrm{VI})$ ions. By increasing the $\mathrm{pH}$ of the solution, the protonated surface of Ch-ACs decreases gradually and the $\mathrm{OH}^{-}$anion increases in the solution, thus an adsorption competition occurs between the anions $\left(\mathrm{OH}^{-}, \mathrm{HCrO}_{4}{ }^{-}\right.$and $\left.\mathrm{CrO}_{4}{ }^{2-}\right)$ leading to a reduction in the efficiency of the $\mathrm{Cr}(\mathrm{VI})$ ion removal [23,28].

On the other hand, $\mathrm{Pb}$ (II) prefers higher $\mathrm{pH}$, with best adsorption in the $\mathrm{pH}$ rang of 4-6 (see Figure 6B). As the figure reveals, the $\mathrm{Pb}$ (II) adsorption increase with increasing $\mathrm{pH}$ (maximum at $\mathrm{pH}$ of 6) and then decreases at higher $\mathrm{pH}$. The $\mathrm{Pb}(\mathrm{II})$ adsorption behavior is opposite that of $\mathrm{Cr}(\mathrm{VI})$. At low $\mathrm{pH}$, the surface of the $\mathrm{AC}$ is highly protonated (increase $\mathrm{H}^{+}$) causing repulsion between the protons and the lead cations (the amino groups of the prepared $\mathrm{Ch}-\mathrm{ACs}$ are positive and cannot capture the $\mathrm{Pb}$ (II) ions). With further increase of the $\mathrm{pH}$, the protonation decreases and the $\mathrm{OH}^{-}$groups increases along with greater deprotonation of the amino groups that lead to the presence of partially negative charge on the surface of the AC. This would increase the interconnection between the surface of AC and the $\mathrm{Pb}(\mathrm{II})$, and, hence, increase the efficiency of $\mathrm{Pb}$ (II) removal from aqueous solutions. With further increase in the $\mathrm{pH}$, hydrolysis of the metal ion occurs, leading to a decrease in the removal efficiency $[33,41]$.

\subsubsection{Effect of Surface Functional Group Modification and AC Initial Dosage}

The main purpose of the surface modification of the Ch-based ACs is to increase the adsorption ability of heavy metals. In this work, AC modification was carried out using a different $\mathrm{N}$-rich compound (Figure 6C,D). It is obvious that the efficiency of the removal $\mathrm{Cr}(\mathrm{VI})$ and $\mathrm{Pb}(\mathrm{II})$ varies with varying these compounds. The best for $\mathrm{Cr}(\mathrm{VI})$ ions removal was AC enriched using Aniline (A), where the removal was up to $99.2 \%$, while for $\mathrm{Pb}(\mathrm{II})$ ions, $\mathrm{U}, \mathrm{DDAB}$, and $\mathrm{DAP}$ give almost the same removal percent, $99.99 \%$. Based on the discussion in Section 3.6.1 above, it is not surprising that the removal of $\mathrm{Cr}(\mathrm{VI})$ ions is much better using $\mathrm{AC}$ without $\mathrm{N}$ enrichment while for the $\mathrm{Pb}(\mathrm{II})$ is the opposites. This is due to the fact that $\mathrm{N}$ has lone pairs of electron and the $\mathrm{Cr}(\mathrm{VI})$ in the solution acts as anion leading to electrostatic repulsion between the metal ions and the surface of the $\mathrm{Ch}$-ACs (Figure 6E). In the case of lead ions, it is the opposite, because $\mathrm{Pb}$ (II) has positive charge while the N-rich surface of the AC possesses lone pairs; as a result, the attraction is favorable (Figure 6F).

Furthermore, the effect of $\mathrm{Ch}-\mathrm{AC}$ dose was studied to select the optimum amount of $\mathrm{AC}$ needed for adsorption. For $\mathrm{Cr}(\mathrm{VI})$ ion removal, increasing the AC dosage increases the adsorption at the binging and then decreased, hence, it was more logical to use the smallest amount of AC (see Figure S5A). This agrees with the study of Abdel-Galil et al., in which they found that over a certain amount of $\mathrm{AC}$, the removal efficiencies remain nearly constant and there is no notable increase in the adsorption above $0.05 \mathrm{~g} / \mathrm{L}$ AC dose [55]. For $\mathrm{Pb}$ (II) ions, there was no notable effect of varying the $\mathrm{AC}$ dosage (the removal was high in all cases (99.9\% and above, see Figure S5B).

\subsubsection{Effect of Heavy Metal Ion Concentrations}

Studying the effect of different initial concentration of the heavy metal ions (Ci) on the adsorption process is important because it varies in a broad range in the industrial discharge. It was noticed in this study that at a fixed $\mathrm{pH}$ and adsorbent dose, increasing the initial $\mathrm{Pb}$ (II) ion concentration is associated with a decrease in the amount of adsorption (see Figure S6). This might be due to the blockage of the adsorbent's active sites by the heavy metal ions (no free adsorption sites are available) [50]. For $\mathrm{Cr}(\mathrm{VI})$ ions, however, the behavior was not regular (increase was followed by decrease). 


\subsubsection{Effect of Contact Time}

The sorption time is known to be a critical parameter due to its importance in finding the time needed for reaching equilibrium and also for knowing the optimum time of the heavy metal ions removal. In this study, it was found that, at the beginning, the adsorption on Ch-ACs was fast and high for both studied heavy metal ions and this is due to the availability of pores on its surface. After some time, the adsorption decreased due to the desorption process that happens in the solution with agitation time and then increased again up to its maximum adsorption (see Figure S7) [25,28]. Figure S8 shows the equilibrium time needed for both $\mathrm{Cr}(\mathrm{VI})$ and $\mathrm{Pb}$ (II). There was an increase in the adsorbate concentration with time $\left(q_{\mathrm{t}}\right)$ at the first stage and then remains almost constant until it reaches equilibrium. The equilibrium of $\mathrm{Cr}(\mathrm{VI})$ ions confirmed to be at around $60 \mathrm{~min}$ while for $\mathrm{Pb}$ (II) ions around $16 \mathrm{~min}$ are needed for the equilibrium to be achieved (see Figure S8). Such fast adsorption of $\mathrm{Pb}$ (II) ions was also confirmed by others [32]. Consequently, $60 \mathrm{~min}$ of shaking time was chosen for all studies.

\subsection{Adsorption Isotherms}

Studying the applicable adsorption isotherms models, such as Langmuir, Freundlich, and Temkin, are important in order to understand the interaction between the adsorbent and the heavy metal ions, and their behavior on the surface of the Ch-based ACs. This is demonstrated in Figure 7 and the calculated parameters of these models are summarized in Table 3. According to the achieved values of the correlation coefficient and the chi-square, the adsorption experiments at $\mathrm{T}=25^{\circ} \mathrm{C}$ show that Temkin and Langmuir have the best fits for $\mathrm{Cr}(\mathrm{VI})$ and $\mathrm{Pb}$ (II) adsorption, respectively (exhibit higher $R^{2}$ and lower $\chi^{2}$ values, see Table 3). The same was found to apply for the other studied temperatures (i.e., 35, 45, 55, and $65{ }^{\circ} \mathrm{C}$, see Figure S9 and Table S1). This indicates that for $\mathrm{Cr}(\mathrm{VI})$ the heat of adsorption decreases, in a linear manner, with the increase of coverage of the adsorbent [49] while for $\mathrm{Pb}$ (II), indicates the consumption of heavy metal ions occurs on a homogeneous surface by monolayer adsorption without interaction between adsorbed ions [39,46]. Langmuir adsorption isotherm is generally acceptable for describing the process when ionic or covalent chemical bonds are formed between the AC and the heavy metals. This indicate the absence of physicochemical reactions between the adsorbed $\mathrm{Pb}$ (II) ions and the surface of AC. One of the necessary Langmuir parameters is the equilibrium parameter, $R \mathrm{~s}$, which is used to determine the degree to which a substance tends to combine with the AC. The values of $R$ s presented in the Table 3 are between zero and unity, which confirms that the adsorption of $\mathrm{Cr}(\mathrm{VI})$ and $\mathrm{Pb}(\mathrm{II})$ ions on the surface of the modified $\mathrm{Ch}$-based $\mathrm{AC}$ is favorable [26].
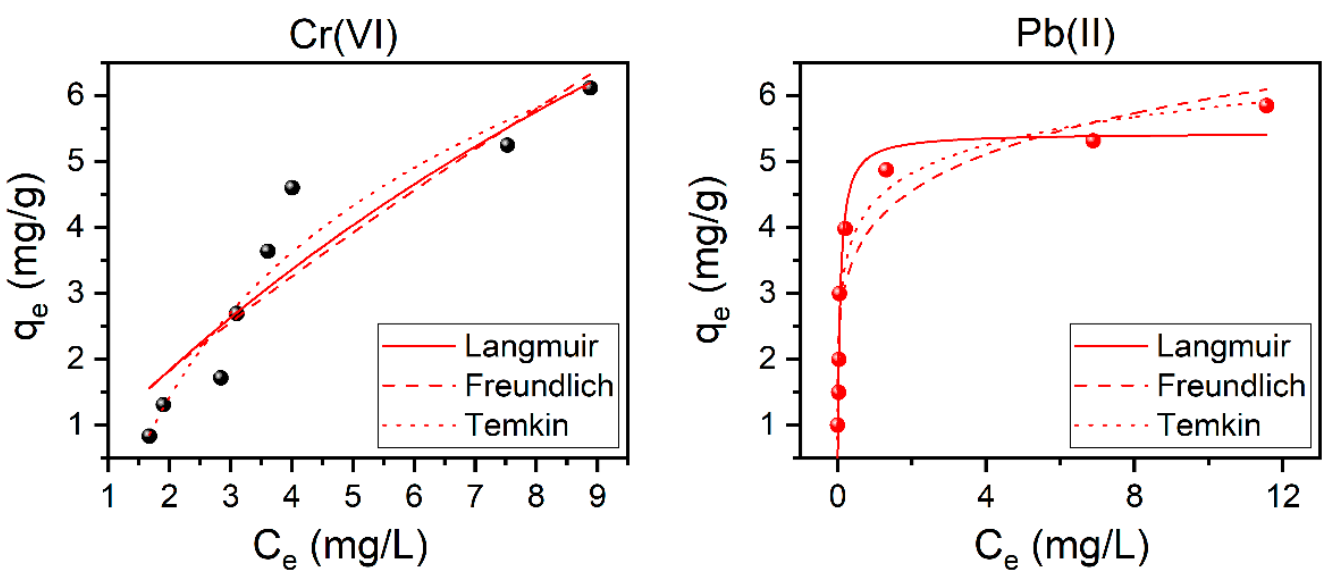

Figure 7. The adsorption isotherms for both $\mathrm{Cr}(\mathrm{VI})$ (right) and $\mathrm{Pb}$ (II) (left) using modified Ch-based AC. Top: Langmuir, middle: Freundlich, bottom: Tekmin, using $10 \mathrm{Ch} 600.60 \mathrm{~K}_{2} \mathrm{CO}_{3} . \mathrm{U}$ as adsorbent. Conditions: $\mathrm{Cr}(\mathrm{VI})$ and $\mathrm{Pb}(\mathrm{II}) \mathrm{Ci}$ : 10-70 mg/L; AC dose: $10 \mathrm{~g} / \mathrm{L} ; \mathrm{Cr}(\mathrm{VI}) \mathrm{pH}: 2, \mathrm{~Pb}(\mathrm{II}) \mathrm{pH}$ : 6; the contact time: $1 \mathrm{~h}$; and $\mathrm{T}: 25^{\circ} \mathrm{C}$. 


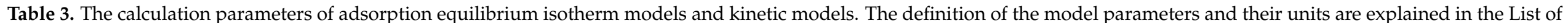

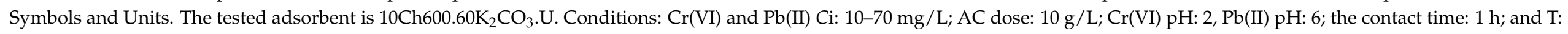
$25{ }^{\circ} \mathrm{C}$.

\begin{tabular}{|c|c|c|c|c|c|c|c|c|c|c|c|c|c|c|c|c|c|c|c|c|c|}
\hline \multirow{3}{*}{ Heavy Metal } & \multicolumn{11}{|c|}{ Isotherms Models } & \multicolumn{10}{|c|}{ Kinetic Models } \\
\hline & \multicolumn{5}{|c|}{ Langmuir } & \multicolumn{4}{|c|}{ Freundlich } & \multicolumn{2}{|c|}{ Tekmin } & \multicolumn{6}{|c|}{ Pseudo-First-Order } & \multicolumn{4}{|c|}{ Pseudo-Second-Order } \\
\hline & $q_{\text {max,cal }} a$ & $K_{\mathrm{L}}$ & $R^{2}$ & $x^{2}$ & $R_{\mathrm{S}}$ & $1 / n$ & $K_{\mathrm{F}}$ & $R^{2}$ & $x^{2}$ & $b_{\mathrm{t}}$ & $K_{\mathrm{T}}$ & $R^{2}$ & $x^{2}$ & $q_{\mathrm{e}, \mathrm{cal}}$ & $k_{\mathrm{pf}}$ & $R^{2}$ & $x^{2}$ & $q_{\mathrm{e}, \mathrm{cal}}$ & $k_{\mathrm{ps}}$ & $R^{2}$ & $x^{2}$ \\
\hline $\mathrm{Cr}(\mathrm{VI})$ & 20.04 & 0.05 & 0.877 & 0.541 & 0.67 & 0.83 & 1.02 & 0.863 & 0.601 & 784 & 0.78 & 0.928 & 0.316 & 0.87 & 1.38 & 0.897 & $3.3 \times 10^{-5}$ & 0.88 & 7.51 & 0.967 & $1.1 \times 10^{-5}$ \\
\hline $\mathrm{Pb}(\mathrm{II})$ & 5.43 & 16.22 & 0.945 & 0.215 & 0.01 & 0.17 & 4.06 & 0.892 & 0.425 & 4016 & 1236.6 & 590.939 & 0.239 & 5.00 & 1.00 & 0.908 & $2.9 \times 10^{-6}$ & 5.00 & 8.91 & 0.916 & $2.6 \times 10^{-6}$ \\
\hline
\end{tabular}

${ }^{a}$ cal stands for model calculated. 


\subsection{Adsorption Kinetics}

In this work, kinetic studies were used to predict the rate at which adsorption takes place, which is the most important factor in adsorption system design and in determining the adsorption efficiency. It shows how fast or slow an adsorption process is and which kinetic order it follows. Pseudo-first and pseudo-second orders of the reaction are two kinetic models usually used to describe the reaction order of adsorption systems. Such kinetic models for the removal of $\mathrm{Cr}(\mathrm{VI})$ ions and $\mathrm{Pb}(\mathrm{II})$ ions are presented in Figure 8 and the calculated parameters were outlined in Table 3. Based on the correlation coefficient (the values of $R^{2}$ ) and the reduced chi-squared values $\left(\chi^{2}\right)$ for the pseudo-second-order kinetics for both $\mathrm{Cr}(\mathrm{VI})$ and, to a less extent, for $\mathrm{Pb}$ (II) (see Table 3), one can conclude that the adsorption process may obey this kinetic model. It is worth mentioning here that by comparing the experimental $q_{\mathrm{e}}$ and the calculated ones $\left(q_{\mathrm{e}, \mathrm{cal}}\right)$ one can see that the values are exactly the same (see the inset values in Figure S8 and those reported in Table 3).
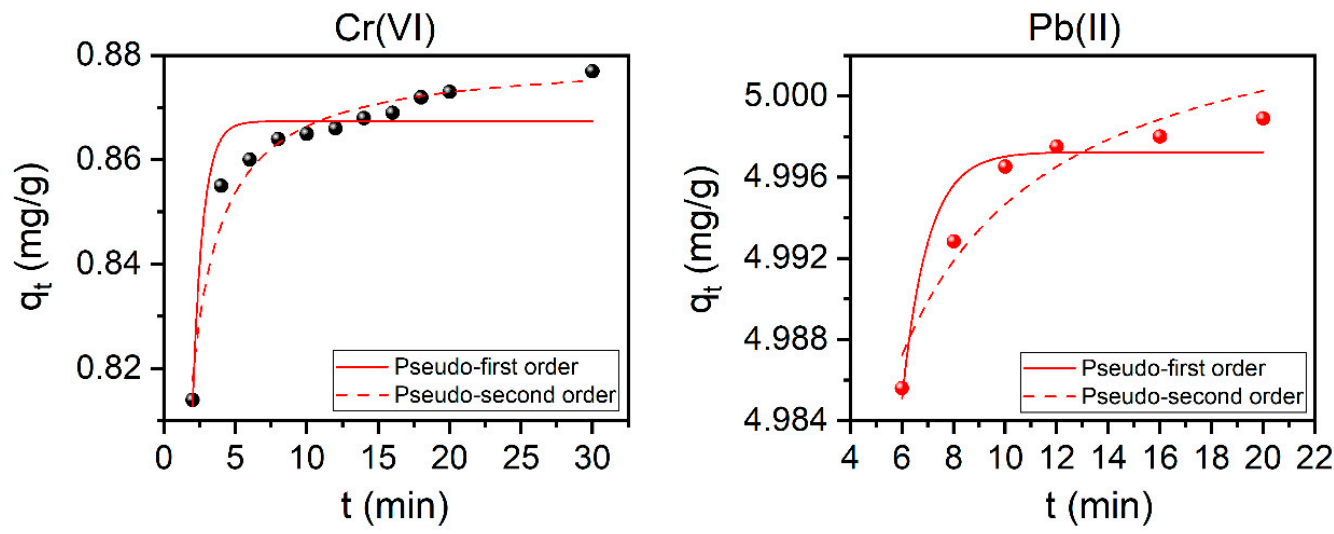

Figure 8. Pseudo-second-order kinetic models for the adsorption of both $\mathrm{Cr}(\mathrm{VI})$ (left) and $\mathrm{Pb}(\mathrm{II})$ (right) ions using the modified Ch-based $\mathrm{AC}\left(10 \mathrm{Ch} 600.60 \mathrm{~K}_{2} \mathrm{CO}_{3} . \mathrm{U}\right)$. Conditions: $\mathrm{Cr}(\mathrm{VI})$ and $\mathrm{Pb}(\mathrm{II})$ Ci: $10 \mathrm{mg} / \mathrm{L}$; AC dose: $10 \mathrm{~g} / \mathrm{L}$; $\mathrm{Cr}(\mathrm{VI}) \mathrm{pH}: 2, \mathrm{~Pb}(\mathrm{II}) \mathrm{pH}: 6$; and T: $25^{\circ} \mathrm{C}$.

\subsection{Adsorption Thermodynamic}

Thermodynamics studies for the adsorption of chromium hexavalent and lead divalent ions on the surface of the Ch-ACs was carried out at different temperature $(25,35,45,55$, and $65^{\circ} \mathrm{C}$ ) under fixed $\mathrm{pH}$ and $\mathrm{AC}$ dose with variation of the initial heavy metal concentration (Ci). The effect of temperature on the adsorption of $\mathrm{Cr}(\mathrm{VI})$ and $\mathrm{Pb}(\mathrm{II})$ ions are summarized in Table 4. The results indicate that the adsorption is exothermic in the case of both $\mathrm{Cr}(\mathrm{VI})$ and $\mathrm{Pb}$ (II) ions (i.e., $\Delta H<0$ ). The nature of the adsorption of these heavy metals was studied by evaluating the thermodynamic parameters (Gibbs free energy, $\Delta G$, enthalpy, $\Delta H$, and entropy, $\Delta S$ ) using the Van 't Hoff equation and the unit-corrected Langmuir constant $\left(K_{\mathrm{L}}{ }^{\text {corr }}\right)$, and the results are reported in Table 4 . The observed negative $\Delta G$ values, for both studied ions, indicate that the adsorptions are spontaneous and favorable. Additionally, the very slight increase in the negative $\Delta G$ value with temperature, as observed for $\mathrm{Pb}(\mathrm{II})$, indicates a favorable adsorption driving force at a higher temperature (see Table 4 and Figure S10). This should not be considered as a drawback since, for $\mathrm{Pb}(\mathrm{II})$, the adsorption efficiencies were very high at all studied temperatures. For $\mathrm{Cr}(\mathrm{VI})$ ions, however, a plot of $q_{\mathrm{e}}$ versus $C_{\mathrm{e}}$ (Figure $\mathrm{S} 10$ ) shows that the adsorption process favors a lower temperature. In spite of such opposite response toward temperature, the equilibrium adsorption capacities for both ions are not much affected by temperature (see Figure S10). The positive value of $\Delta \mathrm{S}$ (much higher for $\mathrm{Pb}(\mathrm{II})$, see Table 4) indicates that the randomness increases at the solid-solution interface during the adsorption process of Ch-based AC. Although both the negative $\Delta H$ and positive $\Delta S$ contribute to the spontaneity of the adsorption process, the entropy change is the main driving force for the adsorption process of $\mathrm{Pb}(\mathrm{II})$, while for $\mathrm{Cr}(\mathrm{VI})$, the influence of the enthalpy is dominating. Some studies reported that the heat released during chemisorption is in the range of $80-200 \mathrm{~kJ} / \mathrm{mol}$ while for physisorption it 
is in the range of 2.1-20.9 $\mathrm{kJ} / \mathrm{mol}$ [33]. In this study, the change in enthalpy of adsorption is $-18.95 \mathrm{~kJ} / \mathrm{mol}$ for $\mathrm{Cr}(\mathrm{VI})$ and $-4.92 \mathrm{~kJ} /$ mole for $\mathrm{Pb}(\mathrm{II})$. One can conclude that the adsorption of both $\mathrm{Cr}(\mathrm{VI})$ and $\mathrm{Pb}(\mathrm{II})$ are of physisorption type [33].

Table 4. Thermodynamic parameters for the adsorption of $\mathrm{Cr}(\mathrm{VI})$ and $\mathrm{Pb}$ (II) on the AC. Conditions: $\mathrm{Cr}(\mathrm{VI})$ and $\mathrm{Pb}(\mathrm{II}) \mathrm{Ci}$ : 10-70 mg/L; AC dose: $10 \mathrm{~g} / \mathrm{L} ; \mathrm{Cr}(\mathrm{VI}) \mathrm{pH}: 2, \mathrm{~Pb}(\mathrm{II}) \mathrm{pH}$ : 6; and the contact time: $1 \mathrm{~h}$.

\begin{tabular}{|c|c|c|c|c|c|c|c|c|}
\hline \multirow[b]{2}{*}{$\mathrm{T}(\mathrm{K})$} & \multicolumn{4}{|c|}{$\mathrm{Cr}(\mathrm{VI})$} & \multicolumn{4}{|c|}{$\mathrm{Pb}(\mathrm{II})$} \\
\hline & $K_{\mathrm{L}}^{\operatorname{corr} a}$ & $\underset{(\mathrm{kJ} / \mathrm{mol})}{\Delta G}$ & $\begin{array}{c}\Delta H \\
(\mathrm{~kJ} / \mathrm{mol})\end{array}$ & $\Delta S(\mathrm{~J} / \mathrm{mol} \mathrm{K})$ & $K_{\mathrm{L}}{ }^{\operatorname{corr} a}$ & $\begin{array}{c}\Delta G \\
(\mathrm{~kJ} / \mathrm{mol})\end{array}$ & $\begin{array}{c}\Delta H \\
(\mathrm{~kJ} / \mathrm{mol})\end{array}$ & $\begin{array}{c}\Delta S \\
(\mathrm{~J} / \mathrm{mol} . \mathrm{K})\end{array}$ \\
\hline 298 & 5850 & -21.49 & -18.95 & 7.96 & $3,360,784$ & -37.23 & -4.92 & 108.58 \\
\hline 308 & 4329 & -21.44 & & & $2,977,464$ & -38.17 & & \\
\hline 318 & 1989 & -20.08 & & & $3,091,424$ & -39.51 & & \\
\hline 328 & 5733 & -23.60 & & & $3,785,544$ & -41.30 & & \\
\hline 338 & 1638 & -20.80 & & & $2,198,392$ & -41.05 & & \\
\hline
\end{tabular}

${ }^{a}$ Dimensionless.

\subsection{Real Wastewater Study}

Adsorption from the real wastewater sample indicated in the experimental part was performed on $10 \mathrm{Ch} 600.60 \mathrm{~K}_{2} \mathrm{CO}_{3}$.U AC sample using the same conditions (AC dose: $10 \mathrm{~g} / \mathrm{L}$, contact time: $1 \mathrm{~h}, \mathrm{~T}=25^{\circ} \mathrm{C}, \mathrm{pH}=6.5$ ). The removal of the heavy metal ions was very efficient, especially for $\mathrm{Cr}$, As, Ni, and Fe which was almost $100 \%$. For $\mathrm{Cu} \mathrm{Mn,} \mathrm{Na,} \mathrm{K,} \mathrm{Ca}$ ions, however, the concertation was reduced to $1.8,2.0,46,360.0,4654.0$, and $10,870.0 \mathrm{mg} / \mathrm{L}$, respectively. More holistic work on real wastewater samples will be carried out in the near future.

\subsection{Efficiency Comparison with Other Adsorbents}

Table 5 compares the adsorption efficiency of the studied $\mathrm{Ch}$-AC with other studied adsorbents. One can see that the $\mathrm{Ch}-\mathrm{AC}\left(10 \mathrm{Ch} 600.60 \mathrm{~K}_{2} \mathrm{CO}_{3} . \mathrm{U}\right)$ prepared in this study exhibits good performance toward the removal of $\mathrm{Cr}(\mathrm{VI})$ and $\mathrm{Pb}$ (II) if compared with other biochars/activated carbons studied at similar conditions. For example, using wood, as a source of AC [25], for the removal of $\mathrm{Cr}(\mathrm{VI})$ at similar $\mathrm{pH}$ used in our study, the efficiency falls between 36 and 72\% (low adsorption at low concentration) while in this study the removal was higher and reaches 99\%. Another example, using Leucaena plant waste [55], as a source of $\mathrm{AC}$, for $\mathrm{Pb}$ (II) removal using a similar amount of $\mathrm{AC}$ used in this study and even higher agitation speed (400 RPM), the removal efficiency was $97 \%$. In this study, the removal of $\mathrm{Pb}(\mathrm{II})$ was $99.99 \%$ even at lower agitation speed (120 rpm).

Table 5. Comparison of adsorption efficiency (\% removal) for $\mathrm{Cr}(\mathrm{VI})$ and $\mathrm{Pb}(\mathrm{II})$ using other adsorbents and the adsorbent used in this study. $\mathrm{C} i=$ the initial concentration of the metal ions; $\mathrm{AD}=$ adsorbent dose; $\mathrm{AS}=$ agitation speed.

\begin{tabular}{|c|c|c|c|c|c|}
\hline Adsorbent Source & Heavy Metal & \% Removal & $\mathrm{T}\left({ }^{\circ} \mathrm{C}\right)$ & Conditions & References \\
\hline Wood & $\mathrm{Cr}(\mathrm{VI})$ & $36-72$ & Room Temp. & $\begin{aligned} \mathrm{pH}=2 ; C i & =5-120 \mathrm{mg} / \mathrm{L} \\
\mathrm{AD} & =1 \mathrm{~g} / \mathrm{L}\end{aligned}$ & [25] \\
\hline Dust coal & $\mathrm{Cr}(\mathrm{VI})$ & $64-66$ & Room Temp. & $\begin{array}{c}\mathrm{pH}=3-4 ; C \mathrm{i}=5-120 \mathrm{mg} / \mathrm{L} ; \\
\mathrm{AD}=1 \mathrm{~g} / \mathrm{L}\end{array}$ & [25] \\
\hline Orange peal & $\mathrm{Cr}(\mathrm{VI})$ & 62.56 & 25 & $\begin{array}{c}\mathrm{pH}=1 ; \mathrm{Ci}=200 \mathrm{mg} / \mathrm{L} \\
\mathrm{AD}=1 \mathrm{~g} / \mathrm{L} ; \mathrm{AS}=200 \mathrm{rpm}\end{array}$ & {$[50]$} \\
\hline Manihot esculenta Crantz & $\mathrm{Cr}(\mathrm{VI})$ & 97.5 & 25 & $\begin{array}{c}\mathrm{pH}=3 ; \mathrm{Ci}=20 \mathrm{mg} / \mathrm{L} ; \\
\mathrm{AD}=0.1 \mathrm{~g} / \mathrm{L} ; \mathrm{AS}=300 \mathrm{rpm}\end{array}$ & [58] \\
\hline Guava seeds & $\mathrm{Cr}(\mathrm{VI})$ & 75-97 & 25 & $\begin{array}{c}\mathrm{pH}=1 ; \mathrm{Ci}=500 \mathrm{mg} / \mathrm{L} ; \\
\mathrm{AD}=6 \mathrm{~g} / \mathrm{L} \\
\mathrm{pH}=3 \cdot \mathrm{Ci}=50 \mathrm{mg} / \mathrm{L}\end{array}$ & [59] \\
\hline Agricultural waste material & $\mathrm{Cr}(\mathrm{VI})$ & 97 & 30 & $\begin{array}{c}\mathrm{pH}=3 ; C \mathrm{i}=50 \mathrm{mg} / \mathrm{L} ; \\
\mathrm{AD}=0.625-5 \mathrm{~g} / \mathrm{L} ; \\
\mathrm{AS}=200 \mathrm{rpm}\end{array}$ & {$[60]$} \\
\hline Banana peels & $\mathrm{Cr}(\mathrm{VI})$ & 96 & 25 & $\begin{array}{c}\mathrm{pH}=3 ; \mathrm{Ci}=400 \mathrm{mg} / \mathrm{L} \\
\mathrm{AD}=4 \mathrm{~g} / \mathrm{L} ; \mathrm{AS}=300 \mathrm{rpm}\end{array}$ & {$[61]$} \\
\hline
\end{tabular}


Table 5. Cont.

\begin{tabular}{|c|c|c|c|c|c|}
\hline Adsorbent Source & Heavy Metal & \% Removal & $\mathrm{T}\left({ }^{\circ} \mathrm{C}\right)$ & Conditions & References \\
\hline Hazelnut shell & $\mathrm{Cr}(\mathrm{VI})$ & $92-99$ & 30 & $\begin{array}{c}\mathrm{pH}=1 ; \mathrm{Ci}=50-300 \mathrm{mg} / \mathrm{L} \\
\mathrm{AD}=2.5 \mathrm{~g} / \mathrm{L} ; \mathrm{AS}=200 \mathrm{rpm}\end{array}$ & [62] \\
\hline Aloe vera waste leaves & $\mathrm{Cr}(\mathrm{VI})$ & 98.89 & 25 & $\begin{array}{c}\mathrm{pH}=1.21 ; \mathrm{Ci}=50 \mathrm{mg} / \mathrm{L} \\
\mathrm{AD}=2 \mathrm{~g} / \mathrm{L} ; \mathrm{AS}=150 \mathrm{rpm}\end{array}$ & [63] \\
\hline Chitosan & $\mathrm{Cr}(\mathrm{VI})$ & 99.2 & 25 & $\begin{array}{c}\mathrm{pH}=2 ; \mathrm{Ci}=10 \mathrm{mg} / \mathrm{L} \\
\mathrm{AD}=10 \mathrm{~g} / \mathrm{L} ; \mathrm{AS}=120 \mathrm{rpm}\end{array}$ & This study \\
\hline Coconut waste & $\mathrm{Pb}(\mathrm{II})$ & 85 & 30 & $\begin{array}{l}\mathrm{pH}=6 ; \mathrm{Ci}=0.15 \mathrm{mmol} / \mathrm{L} ; \\
\mathrm{AD}=1 \mathrm{~g} / \mathrm{L} ; \mathrm{AS}=200 \mathrm{rpm}\end{array}$ & {$[64]$} \\
\hline Nano-silversol & $\mathrm{Pb}(\mathrm{II})$ & 90 & 25 & $\begin{array}{c}\mathrm{pH}=5.5 ; \mathrm{Ci}=100-500 \mathrm{mg} / \mathrm{L} ; \\
\mathrm{AD}=25 \mathrm{~g} / \mathrm{L} ; \mathrm{AS}=120 \mathrm{rpm}\end{array}$ & {$[65]$} \\
\hline Leucaena plant wastes & $\mathrm{Pb}(\mathrm{II})$ & 97 & 25 & $\begin{array}{c}\mathrm{pH}=5 ; \mathrm{Ci}=50 \mathrm{mg} / \mathrm{L} \\
\mathrm{AD}=10 \mathrm{~g} / \mathrm{L} ; \mathrm{AS}=400 \mathrm{rpm}\end{array}$ & [55] \\
\hline Hazelnut husks & $\mathrm{Pb}(\mathrm{II})$ & 99.6 & 18 & $\begin{array}{c}\mathrm{pH}=5.7 ; \mathrm{Ci}=30 \mathrm{mg} / \mathrm{L} \\
\mathrm{AD}=12 \mathrm{~g} / \mathrm{L} ; \mathrm{AS}=200 \mathrm{rpm}\end{array}$ & [66] \\
\hline Conocarpus pruning waste & $\mathrm{Pb}(\mathrm{II})$ & $\approx 100$ & 25 & $\begin{array}{c}\mathrm{pH}=5 ; \mathrm{Ci}=50 \mathrm{mg} / \mathrm{L} ; \\
\mathrm{AD}=1.25 \mathrm{~g} / \mathrm{L} ; \mathrm{AS}=150 \mathrm{rpm}\end{array}$ & [67] \\
\hline Date pits & $\mathrm{Pb}(\mathrm{II})$ & 56 & 25 & $\begin{array}{c}\mathrm{pH}=5.2 ; \mathrm{Ci}=100 \mathrm{mg} / \mathrm{L} \\
\mathrm{AD}=0.2 \mathrm{~g}\end{array}$ & [68] \\
\hline Fruit industry waste & $\mathrm{Pb}(\mathrm{II})$ & 90 & 22 & $\begin{array}{c}\mathrm{pH}=6 ; \mathrm{Ci}=50 \mathrm{mg} / \mathrm{L} ; \\
\mathrm{AD}=4 \mathrm{~g} / \mathrm{L} ; \mathrm{AS}=140 \mathrm{rpm}\end{array}$ & [31] \\
\hline Prunus armeniaca & $\mathrm{Pb}(\mathrm{II})$ & 95 & 22 & $\begin{array}{c}\mathrm{pH}=6 ; C \mathrm{i}=100 \mathrm{mg} / \mathrm{L} \\
\mathrm{AD}=2 \mathrm{~g} / \mathrm{L} ; \mathrm{AS}=140 \mathrm{rpm}\end{array}$ & [56] \\
\hline Chitosan & $\mathrm{Pb}(\mathrm{II})$ & 99.99 & 25 & $\begin{array}{c}\mathrm{pH}=6 ; \mathrm{Ci}=10 \mathrm{mg} / \mathrm{L} ; \\
\mathrm{AD}=10 \mathrm{~g} / \mathrm{L} ; \mathrm{AS}=120 \mathrm{rpm}\end{array}$ & This study \\
\hline
\end{tabular}

\section{Conclusions}

The present study demonstrates a successful preparation of Ch-based ACs with highly porous, $\mathrm{N}$-enriched $(16 \%)$, and highly efficient biosorbent, which was tested for the removal of both $\mathrm{Cr}(\mathrm{VI})$ and $\mathrm{Pb}(\mathrm{II})$ ions. The present study shows also that the $\mathrm{pH}$ of the solution is an important parameter in determining the removal efficiency which is due to its effect on the surface charges and functionality of the prepared AC and also due to the charge of the targeted heavy metal ions. Modification with different $\mathrm{N}$-enrichment agents resulted in excellent removal of the $\mathrm{Pb}$ (II) cations $\left(\mathrm{Pb}^{2+}\right)$ and, to a lesser extent, the $\mathrm{Cr}(\mathrm{VI})$ anions $\left(\mathrm{HCrO}_{4}{ }^{-}, \mathrm{CrO}_{4}{ }^{2-}\right)$. Thermodynamic parameters indicate that the adsorption process by $\mathrm{Ch}$-based $\mathrm{AC}$ is spontaneous (favorable at all studied temperatures) and exothermic in nature for both $\mathrm{Cr}(\mathrm{VI})$ and $\mathrm{Pb}(\mathrm{II})$. For both ions, but more pronounced for $\mathrm{Pb}(\mathrm{II})$, the randomness increases during the adsorption process.

Supplementary Materials: The following are available online at https: / www.mdpi.com/article / 10.3390/nano11081907/s1, Figure S1: Particle size distribution of the prepared AC, with different activator (A), with different volume (B), and with $\mathrm{N}$ enrichment as post- and pretreatment method (C); Figure S2: FTIR spectra of pure Ch; Figure S3: FTIR spectra of Ch-based AC before and after removal of heavy metals; Figure S4: TGA-DTA curves of Ch; Figure S5: The effect of AC dose on the removal efficiency of $\mathrm{Cr}(\mathrm{VI})(\mathrm{A})$ and $\mathrm{Pb}(\mathrm{II})(\mathrm{B})$ ions; Figure S6: The effect of initial heavy metal ions concentration $(\mathrm{Ci})$ on the removal efficiency of $\mathrm{Cr}(\mathrm{VI})(\mathrm{A})$ and $\mathrm{Pb}(\mathrm{II})$ (B) ions; Figure S7: The effect of contact time on the removal efficiency of $\mathrm{Cr}(\mathrm{VI})(\mathrm{A})$ and $\mathrm{Pb}(\mathrm{II})(\mathrm{B})$ ions; Figure S8: Effect of time on the $\mathrm{Cr}(\mathrm{VI})(\mathrm{A})$ and $\mathrm{Pb}(\mathrm{II})(\mathrm{B})$ ions removal from aqueous solution, to determining the $q_{\mathrm{e}}$ as indicated on the plots; Figure S9: The adsorption isotherms for $\mathrm{Cr}(\mathrm{VI})$ and $\mathrm{Pb}(\mathrm{II})$ using modified $10 \mathrm{Ch} 600.60 \mathrm{~K}_{2} \mathrm{CO}_{3}$.U as adsorbent, Table S1: The calculation parameters of adsorption equilibrium isotherm models and kinetic models. The definition of the model parameters and their units are explained in the List of Symbols and Units in the main manuscript. The tested adsorbent is $10 \mathrm{Ch} 600.60 \mathrm{~K}_{2} \mathrm{CO}_{3} . \mathrm{U}$, Figure S10. The adsorption isotherms for $\mathrm{Cr}(\mathrm{VI})(\mathrm{A})$ and $\mathrm{Pb}(\mathrm{II})(\mathrm{B})$ at different temperature using modified $10 \mathrm{Ch} 600.60 \mathrm{~K}_{2} \mathrm{CO}_{3} . \mathrm{U}$ as adsorbent. The definition of the model parameters and their units are explained in the List of Symbols and Units in the main manuscript. 
Author Contributions: Conceptualization, A.B. and J.P.L.; data curation, F.H.E.; formal analysis, F.H.E. and A.B.; funding acquisition, A.B.; investigation, F.H.E.; methodology, A.B. and J.P.L.; project administration, A.B. and J.P.L.; supervision, A.B. and J.P.L.; writing—original draft, F.H.E.; Writing-review and editing, A.B. and J.P.L. All authors have read and agreed to the published version of the manuscript.

Funding: This research was funded by the College of Graduate Studies at Kuwait University, the Kuwait Foundation for the Advancement of Sciences, KAFS (project no. PN1724SC03).

Institutional Review Board Statement: Not applicable.

Informed Consent Statement: Not applicable.

Data Availability Statement: The data presented in this study are available in [the article and supplementary material].

Acknowledgments: This research was funded and supported by the College of Graduate Studies at Kuwait University, the Kuwait Foundation for the Advancement of Sciences, KAFS (project no. PN1724SC03), the RSPU general facilities at Kuwait university (under Grant Number's GS 01/01, GS 01/03, GS 01/05, GE01/07, GS 03/01, GS02/01 and GS 02/08), and the Nanoscopy Science Center at the College of Science. Their supports are appreciated and acknowledged.

Conflicts of Interest: The authors declare no conflict of interest. The funders had no role in the design of the study; in the collection, analyses, or interpretation of data; in the writing of the manuscript, or in the decision to publish the results.

\begin{tabular}{|c|c|}
\hline \multicolumn{2}{|c|}{ Abbreviations, Symbols and Units } \\
\hline $\mathrm{Ch}$ & Chitosan \\
\hline Ch600 & Chitosan carbonized at $600{ }^{\circ} \mathrm{C}$ \\
\hline $\mathrm{AC}$ & Activated carbon \\
\hline Ch-AC & Chitosan-based activated carbon \\
\hline $5 \mathrm{Ch} 600.20 \mathrm{Na}_{2} \mathrm{CO}_{3}$ & $5 \mathrm{~g}$ chitosan carbonized at $600^{\circ} \mathrm{C}$ with $20 \mathrm{~mL}$ sodium carbonate \\
\hline $10 \mathrm{Ch} 600.60 \mathrm{~K}_{2} \mathrm{CO}_{3} \cdot \mathrm{U}$ & $\begin{array}{l}10 \mathrm{~g} \text { chitosan carbonized at } 600^{\circ} \mathrm{C} \text { with } 60 \mathrm{~mL} \text { potassium carbonate } \\
\text { activator and then carbonized again with urea }\end{array}$ \\
\hline 10Ch600.U. $60 \mathrm{~K}_{2} \mathrm{CO}_{3}$ & $\begin{array}{l}10 \mathrm{~g} \text { chitosan carbonized at } 600^{\circ} \mathrm{C} \text { first with urea and then carbonized } \\
\text { again with } 60 \mathrm{~mL} \text { potassium carbonate }\end{array}$ \\
\hline EA & Ethyl amine \\
\hline HA & Hexyl amine \\
\hline DAP & Diamine propane \\
\hline DDA & Didodecyl amine \\
\hline DDAB & Dimethyldidodecylammonium bromide \\
\hline A & Aniline \\
\hline PSD & Pore size distribution \\
\hline$C_{\mathrm{e}}$ & Equilibrium heavy metal concentration (mg/L) \\
\hline$C_{\mathrm{i}}$ & Initial heavy metal concentration (mg/L) \\
\hline$C_{\mathrm{f}}$ & Final heavy metal concentration (mg/L) \\
\hline$q_{\mathrm{e}}$ & Amount of heavy metal adsorbed at equilibrium (mg/g) \\
\hline$q_{\mathrm{e}, \mathrm{cal}}$ & The amount of heavy metal ions adsorbed, as calculated by the model \\
\hline$q_{\mathrm{t}}$ & Amount of heavy metal adsorbed at time, $\mathrm{t}(\mathrm{mg} / \mathrm{g})$ \\
\hline$k_{\mathrm{pf}}$ & Equilibrium efficiency constant of pseudo-first-order adsorption $\left(\mathrm{min}^{-1}\right)$ \\
\hline$k_{\mathrm{ps}}$ & Equilibrium efficiency constant of pseudo-second-order adsorption ( $\mathrm{g} / \mathrm{mg} \mathrm{min})$ \\
\hline$q_{\max }$ & Theoretical maximum amount of $\mathrm{Cr}(\mathrm{VI})$ or $\mathrm{Pb}(\mathrm{II})$ adsorbed (mg/g) \\
\hline $1 / n$ & Freundlich isotherm constant related to adsorption intensity (dimensionless) \\
\hline$K_{\mathrm{L}}$ & Langmuir constant (L/mg) \\
\hline$K_{\mathrm{L}}{ }^{\text {corr }}$ & Corrected Langmuir constant to become dimensionless \\
\hline$K_{\mathrm{F}}$ & Freundlich constant $(\mathrm{mg} / \mathrm{g})(\mathrm{L} / \mathrm{mg})^{1 / \mathrm{n}}$ \\
\hline $\mathrm{b}$ & Langmuir constant at a temperature $\mathrm{T}$ in kelvin \\
\hline A & $\begin{array}{l}\text { Temkin's isotherm constant that estimate the heat of sorption }(\mathrm{J} / \mathrm{mol}) \\
\text { at equilibrium }\end{array}$ \\
\hline$K_{\mathrm{T}}$ & Temkin constant $(\mathrm{L} / \mathrm{mg})$ \\
\hline$R_{\mathrm{S}}$ & Dimensionless separation factor \\
\hline$R^{2}$ & Correlation coefficient \\
\hline
\end{tabular}




\section{References}

1. Yardim, M.F.; Budinova, T.; Ekinci, E.; Petrov, N.; Razvigorova, M.; Minkova, V. Removal of mercury (II) from aqueous solution by activated carbon obtained from furfural. Chemosphere 2003, 52, 835-841. [CrossRef]

2. Rezma, S.; Birot, M.; Hafiane, A.; Deleuze, H. Physically activated microporous carbon from a new biomass source: Date palm petioles. C. R. Chim. 2017, 20, 881-887. [CrossRef]

3. Al-Lagtah, N.M.A.; Al-Muhtaseb, A.H.; Ahmed, M.N.M. Chemical and physical characteristics of optimal synthesized activated carbons from grass-derived sulfonated lignin versus commercial activated carbons. Microporous Mesoporous Mater. 2016, 225, 504-514 [CrossRef]

4. Jeirani, Z.; Niu, C.H.; Soltan, J. Adsorption of emerging pollutants on activated carbon. Rev. Chem. Eng. 2016, 72, 1-32. [CrossRef]

5. Zabini, M.; Ahmadpour, A.; Asl, A.H. Removal of mercury from water by carbonaceous sorbents derived from walnut shell. J. Hazard. Mater. 2009, 167, 230-236. [CrossRef]

6. El-Shafey, E.I.; Ali, S.N.F.; Al-Busafi, S.; Al-lawati, H.A.J. Preparation and characterization of surface functionalized activated carbons from date palm leaflets and applications for methylene blue removal. J. Environ. Chem. Eng. 2016, 4, 2213-3437. [CrossRef]

7. Palomo, J.; Ternero-Hidalgo, J.J.; Rosas, J.M.; Rodríguez-Mirasol, J.; Cordero, T. Selective nitrogen functionalization of phosphorous-containing activated carbons. Fuel Process. Technol. 2016, 156, 438-445. [CrossRef]

8. Ko, J.A.; Park, H.J.; Hwang, S.J.; Park, J.B.; Lee, J.S. Preparation and characterization of chitosan microparticles intended for controlled drug delivery. Int. J. Pharm. 2002, 249, 165-174. [CrossRef]

9. Alves, N.M.; Mano, J.F. Chitosan derivatives obtained by chemical modifications for biomedical and environmental applications. Int. J. Boil. Macromol. 2008, 43, 401-414. [CrossRef] [PubMed]

10. Lee, I.; Park, J.-A.; Kim, J.-H.; Kang, J.-K.; Lee, C.-G.; Kim, S.-B. Functionalization of activated carbon fiber through iron oxide impregnation for $\mathrm{As}(\mathrm{V})$ removal: Equilibrium, kinetic, and thermodynamic analyses. Desalin. Water Treat. 2015, 57, 1-10. [CrossRef]

11. Quesada, H.B.; Araújo, T.P.; Vareschini, D.T.; Barros, M.A.S.D.; Gomes, R.G.; Bergamasco, R. Chitosan, alginate and other macromolecules as activated carbon immobilizing agents: A review on composite adsorbents for the removal of water contaminants. Int. J. Biol. Macromol. 2020, 164, 2535-2549. [CrossRef]

12. Wróbel-Iwaniec, I.; Díez, N.; Gryglewicz, G. Chitosan-based highly activated carbons for hydrogen storage. Int. J. Hydrogen Energy 2015, 40, 5788-5796. [CrossRef]

13. Leżańska, M.; Olejniczak, A.; Pacuła, A.; Szymański, G.; Włoch, J. The influence of microporosity creation in highly mesoporous $\mathrm{N}$-containing carbons obtained from chitosan on their catalytic and electrochemical properties. Catal. Today 2014, 227, $223-232$. [CrossRef]

14. Liu, Y.; Zhao, Y.; Li, K.; Wang, Z.; Tian, P.; Liu, D.; Yang, T.; Wang, J. Activated carbon derived from chitosan as air cathode catalyst for high performance in microbial fuel cells. J. Power Sources 2018, 378, 1-9. [CrossRef]

15. Wu, Q.; Liang, D.; Ma, X.; Lu, S.; Xiang, Y. Chitosan-based activated carbon as economic and efficient sustainable material for capacitive deionization of low salinity water. RSC Adv. 2019, 9, 26676-26684. [CrossRef]

16. Amouzgar, P.; Vakili, M.; Seng, C.E.; Salamatinia, B. Effects of beading parameters for development of chitosan-nano-activated carbon biocomposite for acetaminophen elimination from aqueous sources. Environ. Eng. Sci. 2017, 34, 11. [CrossRef]

17. Auta, M.; Hameed, B.H. Coalesced chitosan activated carbon composite for batch and fixed-bed adsorption of cationic and anionic dyes. Colloids Surf. B 2013, 105, 199-206. [CrossRef]

18. Ahmed, S.; Ahmed, A.; Rafat, M. Performance of chitosan derived activated carbon in supercapacitor. Adv. Nat. Sci. Nanosci. Nanotechnol. 2019, 10, 025003. [CrossRef]

19. Olejniczak, A.; Lezanska, M.; Wloch, J.; Kucinska, A.; Lukaszewicz, J.P. Novel nitrogen-containing mesoporous carbons prepared from chitosan. J. Mater. Chem. A 2013, 1, 8961-8967. [CrossRef]

20. Kucinska, A.; Cyganiuk, A.; Lukaszewicz, J.P. A microporous and high surface area active carbon obtained by the heat- treatment of chitosan. Carbon 2012, 50, 3092-3116. [CrossRef]

21. Fujiki, J.; Yogo, K. Increased $\mathrm{CO}_{2}$ adsorption performance of chitosan derived activated carbons with nitrogen-doping. Chem. Commun. 2015, 52, 186-189. [CrossRef]

22. Ilnicka, A.; Lukaszewicz, J.P. Synthesis of N-rich microporous carbon materials from chitosan by alkali activation using $\mathrm{Na}_{2} \mathrm{CO}_{3}$. Mater. Sci. Eng. B 2015, 201, 66-71. [CrossRef]

23. Ren, L.; Xu, J.; Zhang, Y.; Zhou, J.; Chen, D.; Chang, Z. Preparation and characterization of porous chitosan microspheres and adsorption performance for hexavalent chromium. Int. J. Biol. Macromol. 2019, 135, 898-906. [CrossRef] [PubMed]

24. Ahmed, M.J.; Hameed, B.H.; Hummadi, E.H. Review on recent progress in chitosan/chitin-carbonaceous material composites for the adsorption of water pollutants. Carbohydr. Polym. 2020, 247, 116699. [CrossRef]

25. Selomulya, C.; Meeyoo, V.; Amal, R. Mechanisms of Cr(VI) removal from water by various types of activated carbons. J. Chem. Technol. Biotechnol. 1999, 74, 111-122. [CrossRef]

26. Moreno-Piraján, J.C.; Giraldo, L. Heavy Metal Ions Adsorption from Wastewater Using Activated Carbon from Orange Peel. J. Chem. 2012, 9, 926-937. [CrossRef]

27. Shafeeyan, M.S.; Daud, W.M.A.W.; Houshmand, A.; Shamiri, A. A review on surface modification of activated carbon for carbon dioxide adsorption. J. Anal. Appl. Pyrol. 2010, 89, 143-151. [CrossRef]

28. Puszkarewicz, A.; Kaleta, J. Chromium (VI) adsorption on modified activated carbons. Appl. Sci. 2019, 9, 3549. [CrossRef] 
29. Shekhawat, K.; Chatterjee, S.; Joshi, B. Chromium Toxicity and its Health Hazards. Int. J. Adv. Res. 2015, 3, 167-172.

30. Nowruzi, R.; Heydari, M.; Javanbakht, V. Synthesis of a chitosan/ polyvinyl alcohol/activate carbon biocomposite for removal of hexavalent chromium from aqueous solution. Int. J. Biol. Macromol. 2020, 147, 209-216. [CrossRef]

31. Pap, S.; Bezanovic, V.; Radonic, J.; Babic, A.; Saric, S.; Adamovic, D.; Sekulic, M.T. Synthesis of highly-efficent functionalized biochars from fruit industry waste biomss for removal of chromium and lead. J. Mol. Liq. 2018, 268, 315-325. [CrossRef]

32. Awual, M.R. Mesoporous composite material for efficient lead (II) detection and removal from aqueous media. J. Environ. Chem. Eng. 2019, 7, 103124. [CrossRef]

33. Zarei, F.; Marjani, A.; Soltani, R. Novel and green nanocomposite-based adsorbents from functionalized mesoporous KGG-1 and chitosan-oleic acid for adsorption of Pb(II). Eur. Polym. J. 2019, 119, 400-409. [CrossRef]

34. Yu, H.; Kim, K.; Kang, M.J.; Hwang, S.Y.; Cha, H.G. Carbon Support with Tunable Porosity Prepared by Carbonizing Chitosan for Catalytic Oxidation of 5-Hydroxylmethylfurfural. ACS Sustain. Chem. Eng. 2019, 7, 3742-3748. [CrossRef]

35. Tsubouchi, N.; Nishio, M.; Mochizuki, Y. Role of nitrogen in pore development in activated carbon prepared by potassium carbonate of lignin. Appl. Surf. Sci. 2016, 371, 301-306. [CrossRef]

36. Wang, P.; Zhang, G.; Chen, W.; Chen, Q.; Jiao, H.; Liu, L.; Wang, X.; Deng, X. Molten Salt Template Synthesis of Hierarchical Porous Nitrogen Containing Activated Carbon Derived from Chitosan for $\mathrm{CO}_{2}$ Capture. ACS Omega 2020, 5, 23460-23467. [CrossRef] [PubMed]

37. Hu, Y.; Wang, H.; Yang, L.; Liu, X.; Zhang, B.; Liu, Y.; Xiao, Y.; Zheng, M.; Lei, B.; Zhang, H.; et al. Preparation of Chitosan-Based Activated Carbon and Its Electrochemical Performance for EDLC. J. Electrochem. Soc. 2013, 160, 321-326. [CrossRef]

38. Lota, K.; Acznik, I.; Sierczynska, A.; Lota, G. The capacitance properties of activated carbon obtained from chitosan as the electrode material for electrochemical capacitors. Mater. Lett. 2016, 173, 72-75. [CrossRef]

39. Liu, Y.; Li, L.; Duan, Z.; You, Q.; Liao, G.; Wang, D. Chitosan modified nitrogen-doped porous carbon composite as a highlyefficient adsorbent for phenolic pollutants removal. Colloids Surf. A Physicochem. Eng. Asp. 2021, 610, 125728. [CrossRef]

40. Pap, S.; Kirk, C.; Bremner, B.; Sekulic, M.T.; Shearer, L.; Gibb, S.W.; Taggart, M.A. Low-cost chitosan-calcite adsorbent development for potential phosphate removal and recovery from wastewater effluent. Water Res. 2020, 173, 115573. [CrossRef]

41. Ge, H.; Fan, X. Adsorption of $\mathrm{Pb}^{2+}$ and $\mathrm{Cd}^{2+}$ onto a Novel Activated Carbon-Chitosan Complex. Chem. Eng. Technol. 2011, 34, 1745-1752. [CrossRef]

42. Zana, R. Ionization of cationic micelles: Effect of the detergent structure. J. Colloid Interface Sci. 1980, 78, 330-337. [CrossRef]

43. Naderi, M. Surface area: Brunauer-Emmett-Teller (BET). In Progress in Filtration and Separation; Steven, E., Ed.; Academic Press: London, UK, 2015; pp. 585-608. [CrossRef]

44. Galarneau, A.; Villemot, F.; Rodriguez, J.; Fajula, F.; Coasne, B. Validity of the t-plot method to assess microporosity in hierarchical micro/mesoporous materials. Langmuir 2014, 30, 13266-13274. [CrossRef] [PubMed]

45. Ojeda, M.L.; Esparza, J.M.; Campero, A.; Cordero, S.; Kornhauser, I.; Rojas, F. On comparing BJH and NLDFT pore-size distributions determined from $\mathrm{N}_{2}$ sorption on SBA-15 substrata. Phys. Chem. Chem. Phys. 2003, 5, 1859-1866. [CrossRef]

46. Langmuir, I. The adsorption of gases on plane surfaces of glass, mica and platinum. J. Am. Chem. Soc. 1918, 40, 1361-1403. [CrossRef]

47. Freundlich, H.M.F. Over the adsorption in solution. J. Phy. Chem. 1906, 57, 385-470. [CrossRef]

48. Temkin, M.J.; Pyzhev, V. Kinetics of Ammonia Synthesis on Promoted Iron Catalysts. Acta Phy. Chem. URSS 1940, 12, 217-222.

49. Liu, Y.; Liu, Y.-J. biosorption isotherms, kinetics and thermodynamics. Sep. Purif. Thechnol. 2008, 61, 229-242. [CrossRef]

50. El Nemr, A.; Aboughaly, R.M.; El Sikaily, A.; Ragab, S.; Masoud, M.S.; Ramadan, M.S. Microporous nano-activated carbon type I derived from orange peel and its application for $\mathrm{Cr}(\mathrm{VI})$ removal from aquatic environment. Biomass Conv. Bioref. 2020. [CrossRef]

51. Lima, E.C.; Anastopoulos, I. A critical review of the estimation of the thermodynamic parameters on adsorption equilibria. Wrong use of equilibrium constant in the van't Hoof equation for calculation of thermodynamic parameters of adsorption. J. Mol. Liq. 2019, 273, 425-434. [CrossRef]

52. Jeon, C.; Park, K.H. Adsorption characteristics of mercury(II) ions using aminated chitosan bead. Water Res. 2005, 39, 3938-3944. [CrossRef]

53. Sun, Y.; Yue, Q.; Gao, B.; Gao, Y.; Li, Q.; Wang, Y. Adsorption of hexavalent chromium on Arundo donax Linn activated carbon amine-crosslinked copolymer. Chem. Eng. J. 2013, 217, 240-247. [CrossRef]

54. Kim, N.D.; Kim, W.; Joo, J.B.; Oh, S.; Kim, P.; Kim, Y.; Yi, J. Electrochemical capacitor performance of N-doped mesoporous carbons prepared by ammoxidation. J. Power Sources 2008, 180, 671-675. [CrossRef]

55. Abdel-Galil, E.A.; Rizk, H.E.; Mostafa, A.Z. Production and characterization of activated carbon from Leucaena plant wastes for removal of some toxic metal ions from waste solutions. Desalin. Water Treat. 2015, 57, 1-12. [CrossRef]

56. Sekulić, M.T.; Pap, S.; Stojanović, Z.; Bošković, N. Efficient removal of priority, hazardous priority and emerging pollutants with prunus armeniaca functionalized biochar from aqueous wastes: Experimental optimization and modelling. Sci. Total Environ. 2018, 613-614, 736-750. [CrossRef]

57. Bahmania, H.; Koushkbaghib, S.; Darabic, M.; ZabihiSahebid, A.; Askarie, A.; Iranif, M. Fabrication of novel chitosan-gPNVCL/ZIF-8 composite nanofibers for adsorption of $\mathrm{Cr}(\mathrm{VI}), \mathrm{As}(\mathrm{V})$ and phenol in a single and ternary systems. Carbohydr. Polym. 2019, 224, 115148. [CrossRef]

58. Belcaid, A.; Beakou, B.H.; El Hassani, K.; Bouhsina, S.; Anouar, A. Efficient removal of Cr(VI) an Co(II) from aqueous solution by activated carbon from manihot esculenta crantz agricultural bio-waste. Water Sci. Technol. 2021, 83, 556-566. [CrossRef] 
59. Masry, B.A.; Madbouly, H.A.; Daoud, J.A. Studies on the potential use of activated carbon from guava seeds (AC-GS) as a prospective sorbent for the removal of $\mathrm{Cr}(\mathrm{VI})$ from aqueous acidic medium. Int. J. Environ. Anal. Chem. 2020. [CrossRef]

60. Dubey, S.P.; Gopal, K. Adsorption of chromium(VI) on low cost adsorbents derived from agricultural waste material: A comparative study. J. Hazard. Mater. 2006, 145, 465-470. [CrossRef] [PubMed]

61. Ali, A.; Saeed, K.; Mabood, F. Removal of chromium(VI) from aqueous medium using chemically modified banana peels as efficient low-cost adsorbent. Alex. Eng. J. 2016, 55, 2933-2942. [CrossRef]

62. Kobya, M. Removal of $\mathrm{Cr}(\mathrm{VI})$ from aqueous solution by adsorption onto hazelnut shell activated carbon: Kinetic and equilibrium studies. Bioresour. Thecnol. 2004, 91, 317-321. [CrossRef] [PubMed]

63. Prajapati, A.K.; Das, S.; Mondal, M.K. Exhaustive studies on toxic $\mathrm{Cr}(\mathrm{VI})$ removal mechanism from aqueous solution using activated carbon of aloe vera waste leaves. J. Mol. Liq. 2020, 307, 112956. [CrossRef]

64. Abdul Rahim, A.; Mohsin, H.M.; Thanabalan, M.; Rabat, N.E.; Saman, N.; Mat, H.; Johari, K. Effective carbonaceous desiccated coconut waste adsorbent for application of heavy metal uptakes by adsorption: Equilibrium, kinetic and thermodynamics analysis. Biomass Bioenerg. 2020, 142, 105805. [CrossRef]

65. Kumar, P.S.; Vincent, C.; Kirthika, K.; Kumar, K.S. Kinetics and equilibrium studies of $\mathrm{Pb}^{2+}$ ion removal from aqueous solutions by use of nano-silversol-coated activated carbon. Braz. J. Chem. Eng. 2010, 27, 339-346. [CrossRef]

66. Imamoglu, M.; Tekir, O. Removal of copper (II) and lead (II) ions from aqueous solutions by adsorption on activated carbon from a new precursor hazelnut husks. Desalination 2008, 228, 108-113. [CrossRef]

67. El-Naggar, A.H.; Alzhrani, A.K.R.; Ahmad, M.; Usman, A.R.A.; Mohan, D.; Ok, Y.S.; Al-Wabel, M. Preparation of activated and non-activated carbon from conocarpus pruning waste as low-cost adsorbent for removal of heavy metal ions from aqueous solution. BioResources 2016, 11, 1092-1107. [CrossRef]

68. Abdulkarim, M.; Abu Al-Rub, F. Adsorption of lead ions from aqueous solution onto activated carbon and chemically-modified activated carbon prepared from date pits. Adsorp. Sci. Technol. 2004, 22, 119-134. [CrossRef] 